\title{
The Beneficial Health Effects of Vegetables and Wild Edible Greens: The Case of the Mediterranean Diet and Its Sustainability
}

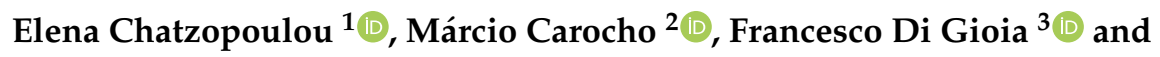 \\ Spyridon A. Petropoulos $4, *$ (D) \\ 1 Kent Business School, University of Kent, Canterbury CT2 7NZ, Kent, UK; e.chatzopoulou@kent.ac.uk \\ 2 Centro de Investigação de Montanha (CIMO), Instituto Politécnico de Bragança, Campus de Santa Apolónia, \\ 5300-253 Bragança, Portugal; mcarocho@ipb.pt \\ 3 Department of Plant Science, Pennsylvania State University, 207 Tyson Building, University Park, PA 16802, \\ USA; fxd92@psu.edu \\ 4 Department of Agriculture Crop Production and Rural Environment, University of Thessaly, Fytokou Street, \\ 38446 Volos, Greece \\ * Correspondence: spetropoulos@uth.gr; Tel.: +30-2421-09-3196
}

Received: 20 November 2020; Accepted: 17 December 2020; Published: 21 December 2020

\begin{abstract}
The Mediterranean diet (MD) concept as currently known describes the dietary patterns that were followed in specific regions of the area in the 1950s and 1960s. The broad recognition of its positive effects on the longevity of Mediterranean populations also led to the adoption of this diet in other regions of the world, and scientific interest focused on revealing its health effects. MD is not only linked with eating specific nutritional food products but also with social, religious, environmental, and cultural aspects, thus representing a healthy lifestyle in general. However, modern lifestyles adhere to less healthy diets, alienating people from their heritage. Therefore, considering the increasing evidence of the beneficial health effects of adherence to the MD and the ongoing transitions in consumers' behavior, the present review focuses on updating the scientific knowledge regarding this diet and its relevance to agrobiodiversity. In addition, it also considers a sustainable approach for new marketing opportunities and consumer trends of the MD.
\end{abstract}

Keywords: agrobiodiversity; antioxidant activity; bioactive compounds; health benefits; medicinal properties; Mediterranean diet; market food trends; sustainability; wild edible greens

\section{Introduction}

Our diet and the proper selection of dietary sources of nutrients are pivotal for our body condition. According to numerous medical studies, these choices can highly influence health conditions [1-4]. The significance of food consumption for human health was first recognized by Hippocrates who quoted "Let food be thy medicine and medicine be thy food". Now, several traditional and/or regional dietary patterns exist throughout the world which are interrelated with cultural, religious, and social beliefs, and are handed from generation to generation. The recent food-based dietary guidelines (FBDGs) for European countries produced by the Food and Agricultural Organization (FAO) and the World Health Organization (WHO) highlight the importance of planning a strategy to promote healthy diets and prevent nutritional deficiencies and/or excesses in the global population [5]. Although the Mediterranean diet (MD) is one of the most well-known dietary patterns that is highly appreciated for its beneficial health effects, a contemporary overview that links the shifts of consumers' behavior towards modern diets and the effects of the MD on diseases is lacking. The health benefits due to adherence to the MD were first introduced in the late 1950's in the Seven Countries Study. The MD dietary pattern 
was probably first referred to using this term by Keys, and it was suggested that the residents of Crete in Greece had the highest life expectancy rates [6-9]. Subsequently, numerous studies have reached the conclusion that the relatively low mortality rates are due to the adherence to the $\mathrm{MD}$, and a large number of scientists have suggested this diet as a prevention factor for cancer, diabetes, and other chronic diseases [10-13]. However, a recent follow-up of the Seven Countries Study revealed that populations now follow dietary patterns that deviate from those followed 50 years ago, and that these changes have resulted in high incidences of obesity, high systolic blood pressure, and hypercholesterolemia [9].

Since 2013, this diet has been considered an Intangible Cultural Heritage by UNESCO based on its values of hospitality, neighborliness, intercultural dialogue, and creativity, and bases its successes on a set of skills, rituals, knowledge, and traditions concerning crops, harvesting, fishing, animal husbandry, conservation, processing, cooking, and the sharing and consumption of food [14].

The MD, as it is now known, is based on a longitudinal study conducted in the early 1960s, and is structured on the food habits of the island of Crete and southern Italy [14]. According to the research of Keys et al. [15], the life expectancy of adult Greek men was the highest in the world, and breast cancer rates in women were less than one-half of those in the United States; however, it should be noted that the existing medical services were limited at that time [16]. The definition of the MD has been subject to continuous update, starting from the early 1960s, when it was suggested to be a diet comprising low consumption of saturated fatty acids and high intake of vegetable oils, followed mostly in Greece and southern Italy [17]. Subsequently, several dietary patterns described as intervention diets and based on the traditional MD, known also as the "modern MedDiets", have been observed. These diets integrate Westernized eating patterns into traditional eating habits [6,18]. Moreover, the local populations of the broader Mediterranean region have continuously interacted with each other throughout a period of centuries, resulting in several common eating habits and food ingredients among the countries around the Mediterranean Sea $[19,20]$. This continuous evolution and adaptation of dietary patterns to new conditions requires a constant reconsideration of the definition of the MD, particularly when considering the recent advances in analytical techniques that allow the effects and the mechanisms responsible for the reported and confirmed health effects to be revealed.

The MD cannot be simply described as a list of foods, because it integrates and constitutes a social, cultural, and rural way of living, e.g., sharing and exchanging food for festivities, celebrations, social, and religious purposes [21]. The MD can be described as a dietary pattern that includes all of the food groups with daily consumption of large portions of cereals, fruits, vegetables, dairy products, and olive oil (as the primary source of fat) [22,23]. Consumption of fish, poultry, and eggs is limited to a few portions per week, and the eating of red meat is restricted to once or twice per month [24]. Vegetables and fruits, in particular, provide one-tenth or more of total calories on a daily basis. However, regarding the consumption of vegetables and fruits in the ancient $\mathrm{MD}$, our knowledge is limited and relies on historical records [25]. The key ingredient of the MD is olive oil, which is the main source of fat. Additionally, olive oil and, in particular, extra-virgin olive oil, is a source of the potent antioxidant vitamin E and polyphenols, it has antioxidant and antithrombotic properties, and according to numerous clinical, meta-analysis, and cohort studies it reduces the risk of coronary disease, diabetes, hypertension, cardiovascular disease-related mortality, and several types of cancer [26-32]. Olive oil has been systematically consumed by the Mediterranean inhabitants for thousands of years with no evidence of harm, although it comprises $28 \%$ and $40 \%$ of energy intake from total fat in southern Italy and Crete, respectively [33]. In addition to the consumption of olive oil, another key element of the traditional MD common to many populations around the Mediterranean basin is the daily consumption of a wide variety of seasonal fresh fruit and vegetables, including underutilized local genetic resources and wild edible plants, which together constitute a rich source of functional food [34,35]. Although the consumption of wild edible plants and local varieties or landraces is strictly linked to the traditional knowledge and rural lifestyle of the Mediterranean populations, the culinary use of food products from such genetic resources is persistent today and offers new opportunities to rediscover the value of the MD. From this perspective, it is important to examine the role that agrobiodiversity played in the traditional $\mathrm{MD}$ and to consider how it may continue to play a key role in the modern MD. 
The relatively recent rapid urbanization in the Mediterranean countries has led to the abandonment of rural life, and the adoption of modern lifestyles and Westernized diets has been followed by increased consumption of meat, animal fats, and dairy products. However, despite these changes, the overall consumption of sugar, meat, and other specific "harmful" food products is less frequent among the citizens of Mediterranean countries compared to North Europeans, although significant differences in the degree of adherence to MD are reported among populations of different Mediterranean countries [36]. Considering the important health effects of the MD and the ongoing transitions in consumers' behavior, the present review focuses on updating the knowledge regarding the health effects related to the adherence to this particular diet, its relevance to agrobiodiversity and the sustainable approach of a healthy diet, and, finally, the new marketing opportunities that have emerged. The compiled information was collected from various databases, such as Scopus, ScienceDirect, PubMed, Google Scholar, and ResearchGate, after searching for specific terms and keywords, e.g., Mediterranean diet and health effects, and agrobiodivesity.

\section{Mediterranean Diet and Agrobiodiversity}

Agrobiodiversity as part of overall biodiversity can be defined as the diversity of living forms within agricultural ecosystems and is strongly linked with diversity in food and agricultural production and, thus, with nutrition and human health. In addition to the diversity of common crop species, Mediterranean agrobiodiversity resources also include wild edible plants [37-42] and the intra-specific diversity expressed by the cultivation of different varieties of the same species, which are often selected locally and called "local landraces" or "local varieties" [43].

In rural areas across the Mediterranean region, it was a usual practice to gather wild plants for food purposes, and many native species are essential ingredients for several traditional dishes. Furthermore, several wild edible plants have been domesticated, and generation after generation, farmers have wisely selected and retained vegetable genotypes with distinct traits, considered to have particular value or utility [43-45].

As we rediscover the value of such agrobiodiversity heritage and its potential contribution to our nutrition security and health, young consumers are reconsidering the virtues of the MD primarily based on the regular consumption of fruit and vegetables, and local landraces of fruit and vegetables and wild edible plants are increasingly appreciated for their nutritional properties and content of bioactive compounds [34,45-52].

During recent decades, the scientific community has greatly contributed to highlighting the value of underutilized genetic resources and to the characterization of their agronomic, nutritional, and functional properties [53]. Furthermore, the local food service industry is sourcing such genetic resources from rural communities and small farms and, with the support of renowned chefs, is contributing to the rediscovery of the use of local landraces and wild edible plants. This is helping to revive and repropose modern versions of traditional dishes that are cornerstone of the MD, thereby contributing to the generation of value and the establishment of a link between agrobiodiversity, local tradition, and the MD. The knowledge generated by the scientific community in synergy with the initiative of the local food service industry is raising the interest of new generations of consumers that are increasingly health conscious and attentive to the quality, origin, and sustainability of their food and diet. These trends are generating new market opportunities, particularly for small-scale farms that often are the custodians of agrobiodiversity resources and local rural traditions in the Mediterranean basin $[34,54,55]$. Linking together local rural traditions, the traditional MD, and smallholder farms that are investing in the cultivation of local landraces or wild edible plants with the modern MD, it is possible to generate community driven "Mediterranean food and cultural hubs", which are capable of educating and sensitizing modern consumers about the role that agrobiodiversity plays or may play in our diet and nutrition. The increasing knowledge and education of new generations about how to apply today the principles of the MD, with the aim of improving their health, will also contribute to preserving and valorizing local rural communities and economies, in addition to protecting the patrimony of agrobiodiversity and agricultural ecosystems. 
The inestimable value of the Mediterranean agrobiodiversity, and its strong link with the MD and its beneficial effects on human health, are increasingly emerging due to the collaborative work of ethnobotanists, horticulturists, plant breeders, food chemists, and nutritionists, who together are recovering and generating new knowledge and genetic material, and are characterizing the nutritional and bioactive profile of many fruit and vegetable local landraces and wild edible species. Agrobiodiversity resources typical of the Mediterranean region, rich in bioactive compounds and commonly included as ingredients of the $\mathrm{MD}$, are, for example, the multiple local landraces and selections of vegetables characterized by different shapes, harvest times, pigmentation, and associated nutritional and bioactive profiles [56,57], such as artichoke and cardoon [58-63], carrots [64-66], chicory and lettuce [67,68] among the Asteraceae family; broccoli and cauliflower [69] and kale [70] among the Brassicaceae family; cultivated and wild garlic [47,48,71-73], and onion [50,74-76] among the Liliaceae family; common beans, cowpea, fabae, and lentils among the Leguminosae family [77-79], melons and watermelons [80-82], or zucchini and squashes [83,84] among the Cucurbitaceae family; and tomato [85-90], pepper [91], and eggplants [92] among the Solanaceous family. Other valuable genetic resources commonly used in the MD and considered rich sources of bioactive compounds include minor vegetable species such as arugula [93-95] and broccoli raab or rapini $[54,96,97]$, and numerous wild edible plants [39,42,44,98-103]. Moreover, the link between agrobiodiversity and MD is also expressed by the variety of plant parts of different species used in the kitchen, which range from roots and other below-ground organs, to stems, leaves or leaf petioles, fruit, and sometimes edible flowers or inflorescences. Exemplary are the cases of the zucchini squash for which, in Southern Italy, stems, young leaves, and flowers are traditionally used, in addition to the courgette [81]; artichoke, for which plant off-shoots are used in addition to the heads; or, the case of rapini, for which leaves and/or inflorescence are commonly used (Figure 1). Similarly, among wild species, the edible parts include leaves and flowers in Borago officinalis; leaves, inflorescence, and roots in Cichorium intybus L.; and in the case of Scolymus hispanicus L., the midribs are used after discarding the spiny leaf-lamina (Figure 2).
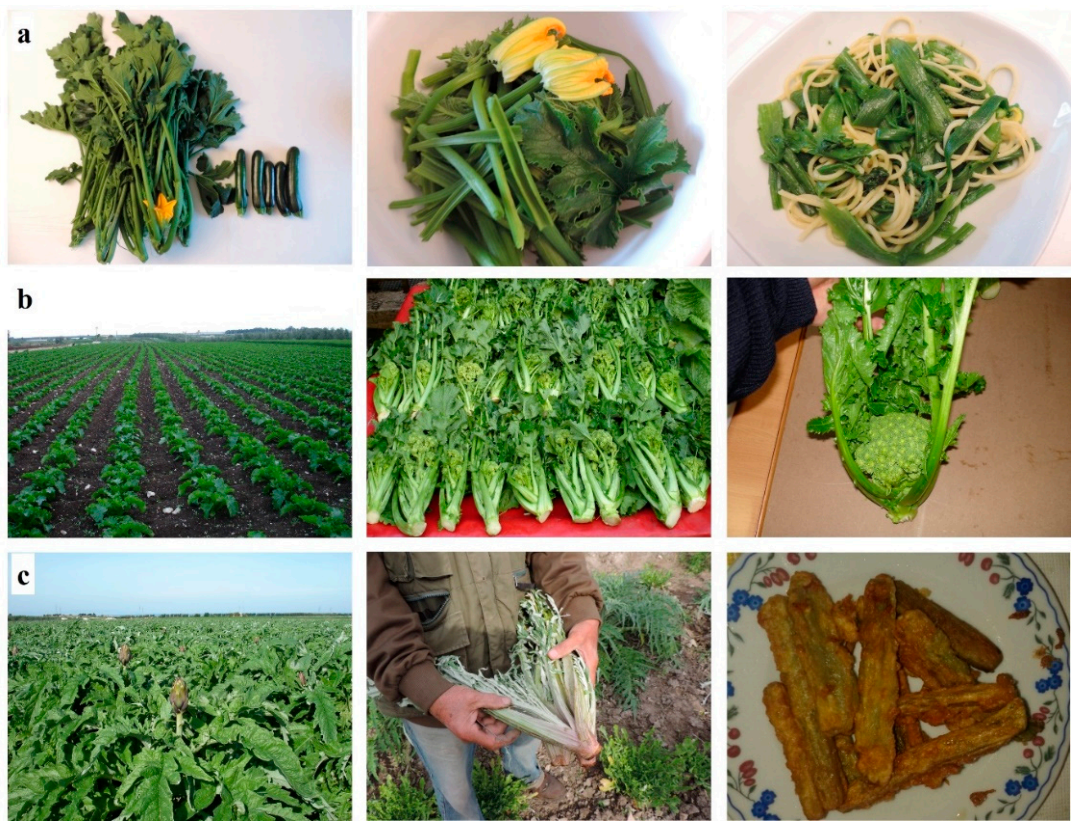

Figure 1. (a) Whole zucchini squash plants harvested to prepare a traditional Italian rural first dish "spaghetti e cime di zucchine" using every portion of the plant, including small fruits, leaves, stems, and flowers. (b) A field of rapini plants and harvested product characterized by the different size of inflorescence (associated with early harvest) in which leaves and inflorescence or only the large inflorescence is used. (c) An artichoke field of the selection "Violet de Provence" with heads ready to harvest, followed by an image of plant off-shoots called "carducci", generated and harvested at the base of the artichoke plant, being used to prepare fried stems. Photo credits: Francesco Di Gioia. 
The increasing demands for healthy and natural food ingredients, in addition to the rediscovery of MD from new generations and the adoption of this particular diet in other regions of the world, necessitates the sustainable management of plant genetic resources [42,98,101,104]. This approach involves various practices, including the cultivation and domestication of wild species and their integration in production systems to promote the sustainability of agro-ecosystems and allow the conservation of valuable genetic resources [37]. The compilation and constant update of FBDGs is also a useful means to promote agrobiodiversity and sustainability through policies and dietary recommendations [5]. Moreover, according to Tarsitano et al. [105] and Burlingame and Dernini [106], the MD or the Mediterranean way encompasses dietary habits and lifestyles, and considers socioeconomic drivers that could be used as a means to achieve the goals set for the 2030 Agenda for Sustainable Development and thus promote biocultural diversity.
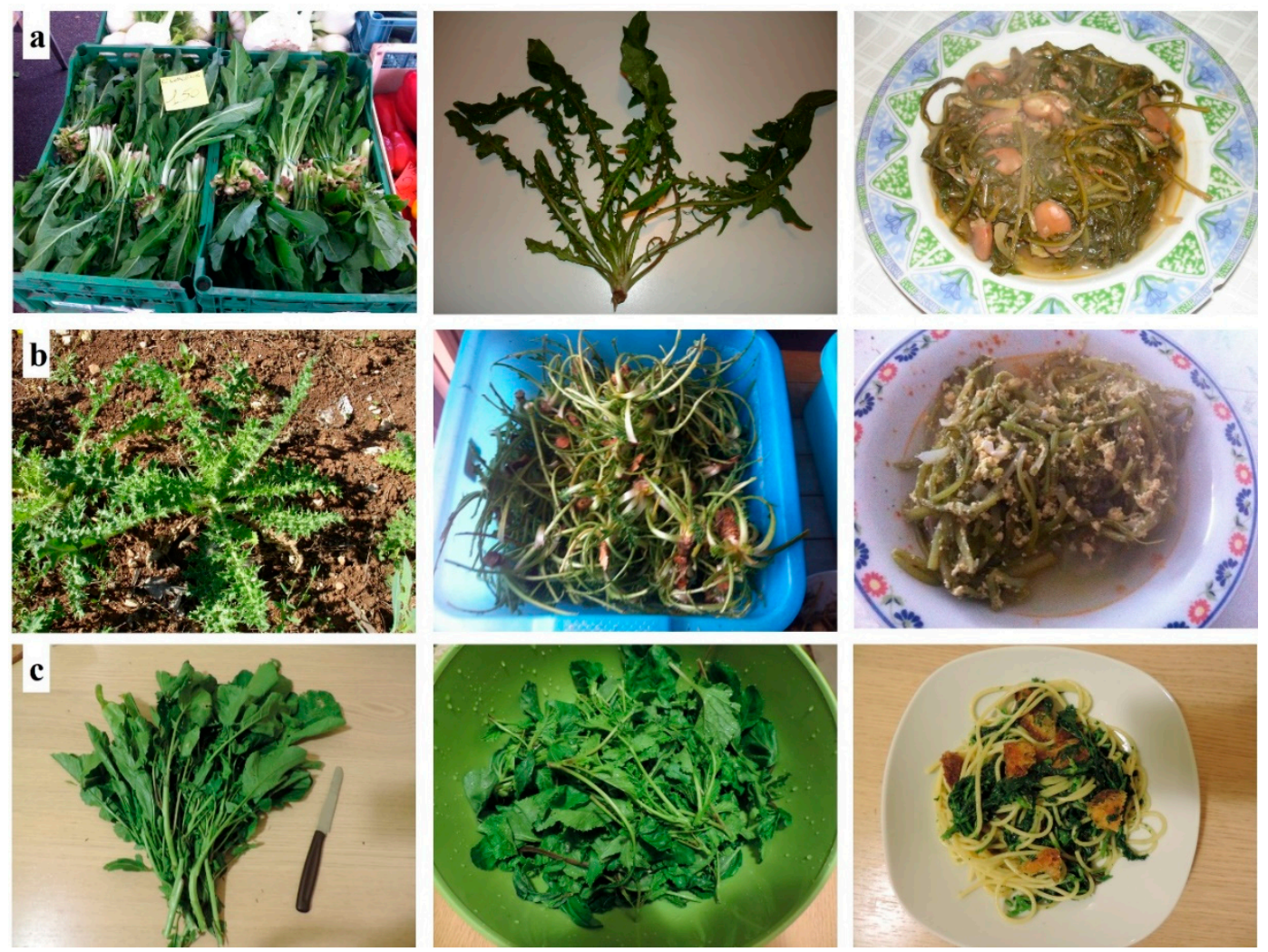

Figure 2. (a) Wild chicory (Cichorium intybus L.) leaves sold in a local farmer's market in Puglia (Italy), whole plant appearance, and a traditional Mediterranean dish prepared combining wild chicory leaves characterized by bitter flavor and dry fava beans characterized by mild taste. (b) Example of wild plants of Scolymus hispanicus L, and midribs cleaned and separated from the spiny lamina and used to prepare a traditional Easter dish with other wild plants and herbs typical of the Murgia (Puglia, Italy), combined with eggs and occasionally lamb. (c) Plants of wild Sinapis alba L. harvested, cleaned, and used to prepare "spaghetti and cime amarelle" a traditional rural dish in Puglia (Italy), revisited according to today's habits using processed pasta instead of traditional whole-grain pasta. Photo credits: Francesco Di Gioia. 
Plant-based diets, including MD, are not only beneficial to human health due to reduced risk factors for several chronic diseases, but they also contribute to environmental sustainability through the adoption of healthy lifestyles [107]. Although MD is sustainable in its conception, the recently identified social and economic trends make it necessary to reevaluate the whole food chain, including crop production, food production, and consumption, also considering environmental, nutritional, economic, and social aspects [106]. Recently, several reports highlighted the importance of commercial cultivation of wild edible greens within the framework of sustainable management of native Mediterranean species and the exigent need for an increase in agrobiodiversity in farming systems, which is threatened by ongoing climate change and monocropping [108-111]. According to a recent report published by the Food and Agriculture Organization of the United Nations, only nine crops contribute $66 \%$ of the global total production of food [37]. The existing cropping systems in most of the Mediterranean countries consist of small-scale farms, which are ideal for the commercial cultivation of high added value crops, such as underutilized wild edible greens [41,55,99,100,102,112-115]. Moreover, the socioeconomic conditions faced by southern European countries during the last decade resulted in limited access to healthy and natural food ingredients that were traditionally used by poor people on a daily basis, because the prices of these food products increased making them affordable only to citizens with high incomes [116]. Several studies revealed that the adherence to MD was higher in social strata that belonged to high socioeconomic status, a finding that was also reflected in higher mortality rates and higher frequencies of chronic diseases among lower social strata [117-119]. Therefore, commercial cultivation of wild species could be a useful means to reduce their production cost, to increase their availability throughout the year, and, finally, to make them more affordable to the general public [110]. Moreover, the domestication and commercial cultivation of wild edible plants allow small-scale farms to obtain more stable yields and guarantee the origin of the product and its hygienic quality, in addition to the conservation of the agro-ecosystem, which may be an issue when collecting spontaneous plants. Although the commercial cultivation of wild edible species may be challenging in many aspects, farmers have successfully repeated this process for a large number of crops. An example of a Mediterranean wild edible species that has been successfully domesticated in recent decades is wild arugula (Diplotaxis tenuifolia (L.) DC.). Today, wild rocket is cultivated globally in open fields and protected environments using both soil and soilless systems. It is available to buy year-round, mostly as a fresh-cut leafy vegetable, and is increasingly appreciated by consumers for its pungent taste and interesting nutritional and bioactive profile $[94,95,120]$. The same path toward domestication and commercial cultivation of similar species could take place and is currently being investigated for many other Mediterranean wild edible species [121-126]. Using advanced sustainable cultivation methods, including soilless cultivation systems and agronomic biofortification techniques, it is possible to use underutilized genetic resources, such as domesticated wild edible plants and vegetable local landraces, to produce functional vegetable products $[42,57,94,98,127,128]$ (Figure 3). In response to new food market trends, some specialized small-scale farms are exploiting Mediterranean wild edible plants and local landraces to produce high-value novel fresh functional products, such as fresh-cut baby leaf, microgreens, and edible flowers, which are increasingly used by chefs to add value, color, and taste to their plates, in addition to being recognized by consumers for their nutritional value and functional properties [129-134] (Figure 3). In addition to creating new market opportunities for small-scale farms, the cultivation of wild edible species and local landraces highly adapted to local environmental conditions may allow the recovery and exploitation of marginal land areas affected by low fertility or high salinity that otherwise could not be used for the production of conventional crops, thereby contributing to preserve marginal Mediterranean agroecosystems and genetic resources at risk of being lost $[41,54,55]$. 

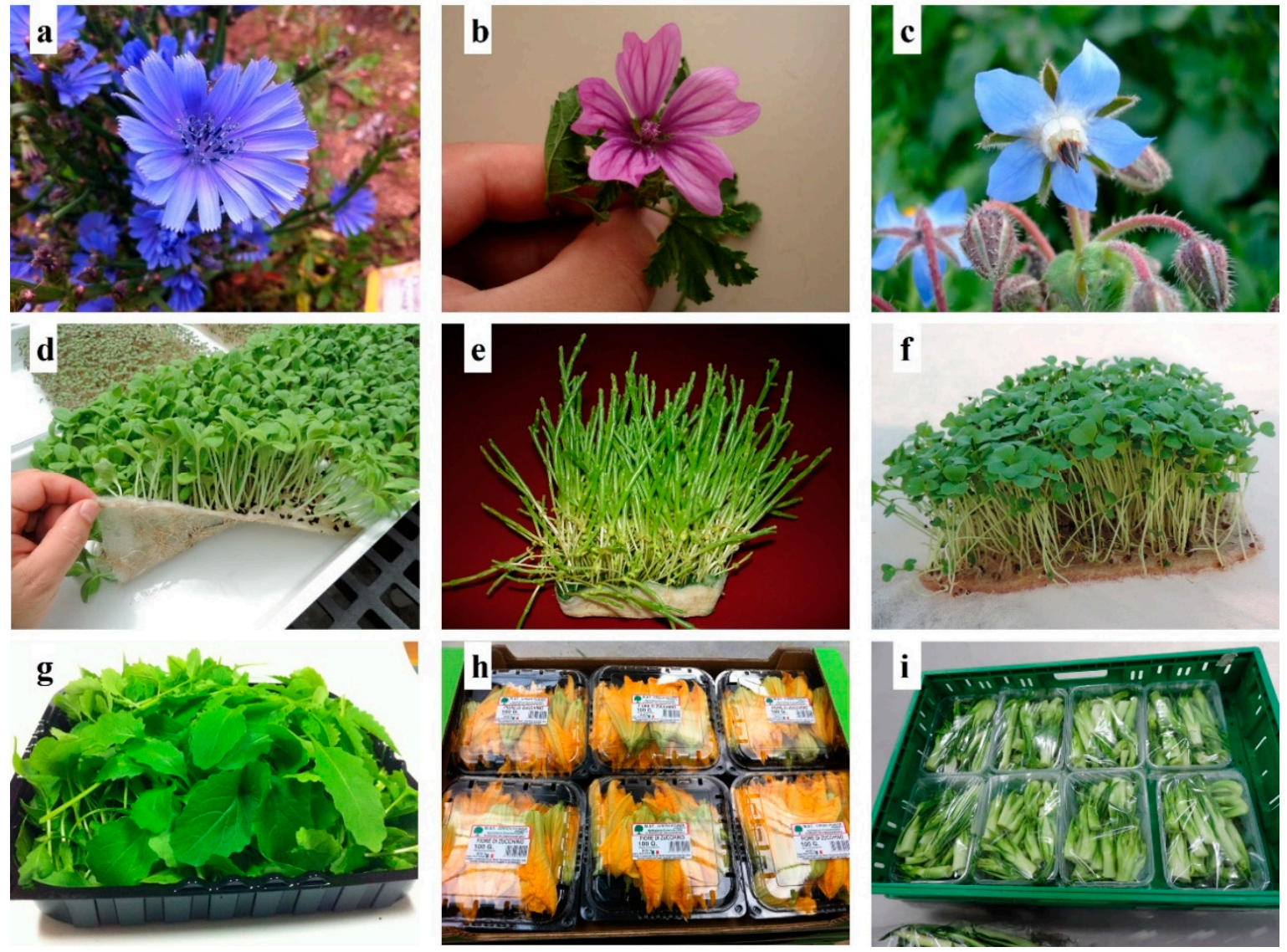

Figure 3. Example of typical Mediterranean wild edible plants and vegetable local landraces suitable to produce edible flowers of (a) Cichorium intybus L., (b) Malva sylvestris L., (c) Borago officinalis L.; microgreens of (d) Borago officinalis L., (e) Salicornia patula Duval-Jouve, (f) Brassica rapa L. Broccoletto group; (g) baby-leaf of Brassica rapa L. selection "Sessantina"; (h) fresh-cut zucchini squash flowers, and (i) fresh-cut stems of Cichorium intybus L. selection 'Molfettese'. Photo credits: Francesco Di Gioia.

\section{The Modern Mediterranean Diet and Its Health Benefits}

Numerous reports highlighted the importance of adopting healthy dietary habits for benefiting the condition and well-being of the human body, focusing on various chronic diseases that impact developed countries, e.g., cancer, cardiovascular diseases, immunomodulatory diseases, diabetes, neurogenerative diseases, myocardial infarctions, and cognitive disorders [135]. The MD has been at the epicenter of research in recent decades, with several beneficial health effects being attributed to the adherence to this particular diet [11,136-139]. Moreover, according to the study of van den Brandt [140], the MD has been highly associated with significant reduction in mortality rates when combined with other lifestyle factors, such as body mass index, smoking, and physical activity.

The following sections provide information regarding the most important health effects of the MD based on clinical and cohort study results.

\subsection{Antioxidant Activity}

The ingredients of the MD contain several antioxidant compounds that have the capacity to protect against cancer, metabolic disorders, aging, and cardiovascular disease, as mentioned in several reports $[12,111,141,142]$. Total antioxidant capacity (TAC) consists of all of the antioxidants that are present in plasma and body fluids, and provides an integrated measurement rather than the simple sum of measurable antioxidants. For example, in the study of Pitsavos et al. [141] TAC was also positively correlated with the consumption of olive oil and fruit and vegetables, whereas it was inversely associated with the consumption of red meat and low oxidized LDL-cholesterol concentrations, which may 
explain the beneficial role of MD on the cardiovascular system. Moreover, according to observational studies, fruit and vegetable consumption showed protective effects against cardiovascular diseases, and possible evidence exists for decreased risk of colon cancer, depression, and pancreatic diseases from fruit intake; and colon and rectal cancer, hip fracture, stroke, depression, and pancreatic diseases from vegetable intake [135]. Mounting reports of the high quantity of antioxidants in the MD have been the subject of cohort studies that attempt to prove the strong correlation between the antioxidants in the diet and the lower incidence of diseases in Mediterranean countries [7,136,143,144]. One example is the study of Billingsley and Carbone [145], which attempted to reveal how the antioxidants may reduce the incidence of cardiovascular diseases in high risk patients. The main conclusion of the study is that the high quantity of polyphenols may in part explain the lower risk for patients following the MD, however, there are limitations to their efficacy. Polyphenols are secondary metabolites which act as free radical scavengers and metal chelators, while they also affect the antioxidant activity of various enzymes [146]. Therefore, a high intake of polyphenols through the diet may improve the defense mechanisms of the human body against several diseases related to oxidative stress $[10,29,147]$. The adherence to Mediterranean-style dietary habits has been associated with reduced risk of diabetes in cohort studies conducted in U.S.A., which highlights the health benefits of the MD [144]. However, further studies are needed to understand if the antioxidants play a major role in the prevention of these cardiovascular diseases, or if it is the result of the combination of various factors (climate, lifestyle, daylight, overall country wealth, socioeconomic status, among others).

\subsection{Life Expectancy Rates}

According to the existing literature, there is an inverse association between mortality and intake of vegetable fats and plant proteins, whereas there is evident positive correlation between mortality and high intake of animal fats, monounsaturated fats of animal origins, and sugar [148]. These coincide with food-based dietary guidelines of the traditional MD and are associated with lower mortality rates, not only for deaths related to chronic diseases, but also overall mortality rates [148]. The data meta-analysis also showed that legumes and olive oil are major food items discriminating subjects between lower or higher mortality rates, and the lipid-lowering effects and/or reduced thrombosis risk, in addition to dietary fiber or vitamin $\mathrm{E}$ intake, could also account for the reduction in mortality rates [136,149]. Other cohort studies and clinical trials have attributed the low mortality rates associated with the MD to the preventive effects of dietary sources against the various types of cardiovascular diseases [136]. The analysis of two epidemiological studies conducted in 2020 involving over 2000 Greek citizens over 50 years old showed that a higher adherence to the MD was associated with a higher level of successful aging [13].

\subsection{Type 2 Diabetes}

According to a study conducted in United States and Spain of 7018 participants, it was suggested that meaningful changes to eating habits, such as low-fat diets and the adoption of variants of the MD including vegetables, fish, legumes, and extra-virgin oil or nuts, may reduce the risks of chronic diseases [150]. In the same study, it was also reported that even individuals who have a genetic predisposition to diabetes due to carrying two copies of a certain gene variant associated with a high risk of developing type 2 diabetes may reduce the risk of developing this disease by following MD eating habits. Furthermore, the MD is considered a healthy approach to control obesity and complications of the cardiovascular system, especially in women in menopause [147]. The mechanisms behind the benefits of the MD towards patients of type 2 diabetes were tentatively explained by Esposito et al. [142], who analyzed the data from eight meta-analyses and five randomized control trials. The authors stated that the benefits of this particular diet are associated with the anti-inflammatory and antioxidative effects from high-quality foods that down-regulate the activation of the innate immune system by reducing the production of proinflammatory cytokines, inducing the production of anti-inflammatory cytokines, thus improving the sensitivity to insulin in peripheral tissues. Moreover, the adherence 
to MD is associated with lower glycosylated hemoglobin levels and improved cardiovascular risk factors compared to diets that have low fat content. Vitale et al. [151] performed a cohort study and investigated the effect of polyphenols intake on cardiovascular risk factors of 2573 type 2 diabetes patients. The results of this study showed that diets rich in polyphenols may improve the cardiovascular risk factor, especially in patients with type 2 diabetes, and they suggested that beneficial effects of such diets could also be extrapolated to the general population [151].

\subsection{Parkinson's Disease (PD)}

Parkinson's disease is a common neurodegenerative disorder which affects approximately $1 \%$ of individuals over the age of 60 years old in North America and Europe. According to literature reports, the association of Parkinson's disease status with MD adherence was significant. Alcalay et al. [152] analyzed a Willett semi-quantitative questionnaire completed by 257 PD participants to score their diet during the preceding year. The findings of this study revealed a positive correlation of the adherence to a Mediterranean-type diet and the reduced rates of PD, and the scores of the Mediterranean-type diet were associated with the earlier onset of PD. Although the mechanisms behind these activities are unknown, it is hypothesized that MD ingredients contain various bioactive phytochemicals that lower inflammation and oxidative stress, which both induce PD pathogenesis [153].

According to the study of Maraki et al. [154], there is a lower probability of prodromal PD in higher MD adherence in older people based on the evaluation of the MD adherence scores. A recent randomized controlled trial involving 80 patients with $\mathrm{PD}$ analyzed the effect of the adherence to the MD for 10 weeks compared to a control group [155]. The findings of this trial suggested a significant improvement in cognitive functions in patients that followed the MD, although the sample size and the short duration of the study do not allow for explicit conclusions.

\subsection{Alzheimer's Disease}

Dietary habits may affect the onset and development of neurodegenerative diseases, such as Alzheimer's disease through the increased resistant of neurons to degeneration [156]. The analysis of dietary patterns and their contribution to cognitive functions may provide useful information regarding the degenerative mechanisms and the prevention of mental dysfunctions, particularly because drugs available to treat Alzheimer's disease have only symptomatic effects and do not delay its development [157]. In the study of Scarmeas et al. [158], the evaluation of a total of 192 individuals diagnosed with Alzheimer's disease showed that adherence to the MD may reduce the mortality rates of patients, and the same dietary pattern may also reduce the risk of this particular disease [156]. The systematic review of Masan et al. [159] evaluated the results of twenty-four studies and suggested that the high intake of $\mathrm{n}-3$ fatty acids and the adherence to MD may have protective effects against age-related cognitive decline. A more recent review identified through numerous studies the positive correlation of the MD and the improvement in the overall cognitive health of middle-aged and older people, although more studies are needed to overcome the problems related with the heterogeneity of scoring systems, in addition to the variability in the evaluation of cognitive outcomes among the various studies [160].

\subsection{Heart Diseases}

The first strong evidence of the beneficial health effects of MD was associated with the lower mortality rates from cardiovascular diseases observed in Greece [6]. Plant-based diets such as MD may contribute to better control of dyslipidemia management in addition to the prevention of cardiovascular diseases (CVD) [4,107]. The effects of MD on risk factors for heart diseases are outlined in several research reports, which conclude that this particular style of diet may decrease the death rates from heart diseases that constitute the main cause of death in developed countries, accounting for about 17 million deaths per year [161]. Carbone et al. [162], who conducted a cross-section animal model study, suggested that high-sugar and high-fat diets such as the modern Western diet resulted in cardiac 
systolic and diastolic dysfunction, which was reversed when subjects were fed with a standard diet. Despite issues with the methodological approaches followed in intervention trials, and meta-analyses reports that raised concerns regarding the postulated beneficial effects of $\mathrm{MD}$ against $\mathrm{CVD}$, a recent critical review report by Martínez-González et al. [163] concluded that these potential controversies are not sufficient to compromise the positive impact of MD on the functions of the cardiovascular system. They also suggested that the existing evidence is strong and consistent, and justifies that the adherence to the MD improves cardiovascular health outcomes through the reductions in rates of coronary heart disease, ischemic strokes, and total cardiovascular diseases. The first evidence of the beneficial effects of the MD was reported in 1950s. Subsequently, numerous clinical trials and epidemiological studies have confirmed the association of this diet with the low incidence of CVD through the improvement of the blood lipid profile [6,164]. A recent clinical study suggested that the consumption of olive oil, which is a key ingredient of the MD, may improve several risk factors of CVD via the diet's antithrombotic and anti-inflammatory activities [27]. Moreover, Estruch et al. [165] compared the short-term impact of two MD ingredients (olive-oil or nuts groups) with a low-fat diet on 772 asymptomatic individuals with high risk of cardiovascular diseases and concluded that, although no clinical outcomes were evaluated, both MDs had beneficial effects against cardiovascular diseases. The short-term effects were associated with the improvement in systolic blood pressure, plasma glucose levels, and the cholesterol-high-density lipoprotein cholesterol ratio [165]. Similar findings were observed by Lee et al. [166], who carried out a controlled crossover study and suggested that following an MD for a 10-day period may improve mood and functions of the cardiovascular system, such as blood systolic pressure. Anagnostis et al. [167] also attributed the beneficial effects of the MD to better blood pressure control and reduction of metabolic syndrome. Long-term cohort studies have also been undertaken, such as that conducted by Buckland et al. [168], who carried out a cohort study with 609 participants who experienced a fatal or nonfatal confirmed acute myocardial infarction or unstable angina requiring revascularization. The authors suggested that high adherence to the MD reduces the risk factors of CVD, particularly the incidents of fatal or nonfatal coronary heart disease events, and the diet should play a significant role in the prevention of coronary heart disease in healthy populations. In the same context, Panagiotakos et al. [169] mentioned the high risk of elevated blood pressure for acute coronary syndromes and the positive effects of the MD in controlling hypertension. Dontas et al. [170] suggested that MD may significantly reduce the development of these syndromes, particularly in the elder population, via the reduction in blood pressure levels and in markers of vascular inflammation. In addition to clinical and epidemiological studies, several other reports highlighted the beneficial effects of various wild edible plants that are commonly consumed in healthy dietary patterns against specific risk factors that may induce cardiovascular diseases, such as Portulaca oleracea [171], Borago officinalis [172], various Asteraceae species [98], and Urtica dioica [173].

\subsection{Cancer}

The risk percentages of numerous types of cancer can be reduced by following a Mediterranean healthy diet [174-177]. Breast cancer is the most common cancer and cause of cancer death in women, accounting for $23 \%$ of all cancers and $13.7 \%$ of cancer deaths [178], and prostate cancer is the second most frequent cancer among men [176]. For both cancer types, the adherence to the MD has been associated with reduced risk and mortality rates [174-176]. The epidemiological data from a case-control study conducted by Turati et al. [174] revealed that high adherence to the MD significantly reduced breast cancer risk, although no adequate information on the breast cancer subtype was available. Moreover, Laudisio et al. [175] suggested that beneficial effects of the MD are associated with the regulation of cell proliferation, induction of apoptosis, and antioxidant activities of single dietary components or the synergistic effects of multiple components. However, although these results are confirmed in postmenopausal women, for premenopausal women, for whom a significantly increased risk of cancer recurrence and higher mortality rate exist, more long-term studies are needed to confirm these results. In the same context, Capurso and Vendemiale [176] analyzed the data from observational 
and case-control studies related to prostate cancer and suggested that MD benefits derive from the high consumption of olive oil, which exerts antioxidant effects and activities on cancer cell signaling and cell cycle progression and proliferation, in addition to tomato sauce, which is rich in lycopene and also exhibits antioxidant properties through the modulation of down-regulation mechanisms of the inflammatory response. According to Coughlin et al. [177] and Di Gioia and Petropoulos [179], plant-based diets are rich in phytoestrogens, which compete with estrogens by binding in estrogen receptors. Moreover, as mentioned by Buckland et al. [143], the MD reduced the risk of breast cancer by $6 \%$ overall, and by $7 \%$ in postmenopausal women, and Bosetti et al. [180] highlighted the role of the MD in reducing the risk factors of pancreatic cancer. According to the review report carried out by Di Daniele et al. [139], the healthy lifestyle associated with MD may reduce the incidences of obesity-related cancer types.

These beneficial activities have been associated with the presence of specific compounds in plants that are commonly used in this dietary pattern, including phenolic compounds, such as hydroxycinnamic and chlorogenic acid [181], saponins [182], flavones and flavonoids [99,101,183,184], tannins [126], polysaccharides [185], glucosinolates [186,187], and other organosulfur compounds [71,188]. The mechanisms involved in the bioactive properties of MD ingredients against cancer have not yet been thoroughly revealed, however, it is hypothesized that they modify the expression of hormones and growth factors that induce cancer pathogenesis [12].

\subsection{Behavioral Effects}

Olive oil, fruits, and vegetables, which are key ingredients of the MD, have shown significant protective effects against cognitive decline and dementia through the attenuation of oxidative stress $[153,189]$. An additional advantage of the MD is its high content in polyunsaturated fatty acids, which are essential for the formation and development of brain tissue [190-192]. According to McMillan et al. [193], who studied the short-term effects of MD, even the adoption of a healthy diet for a 10-day interval may improve the mood and cognitive performance in healthy individuals. This evidence was also supported by the study of Wade et al. [189], who evaluated the MD scores of populations outside the Mediterranean basin over a 5 year period, and concluded that the adherence to the MD may improve the global cognitive health and specific cognitive functions. Moreover, Ferrer-Cascales et al. [194] associated the adherence to the MD with the attenuation of loneliness perception and isolation through the mediation of stress. The study of Ferrer-Cascales et al. [194] also revealed an interrelationship between the degree of adherence to the MD, alcohol intake, emotional eating, and anxiety in student subjects, highlighting the importance of the implementation of educational programs to promote healthy habits among young populations.

Table 1 summarizes different studies, namely, observational, cohort, meta-analysis, randomized control analysis (RCA), systematic reviews, and cross-sectional analysis, in which the benefits of adherence to the MD in human health are identified. Overall, these references prove that this diet is beneficial against many diseases, namely, cardiovascular, neurological, cancer, renal, and others. Nonetheless, a large number of these studies also state that, although evidence of the benefits of the diet has mounted, other tools should be used to prove beyond a doubt its influence, namely, studies in countries that do not adhere to the MD, or regions where the genetic background is different from that of the population in the Mediterranean area. 
Table 1. Representation of different types of studies involving humans, in which positive effects of the consumption of the Mediterranean diet were found. Some references focus on various published studies and thus the number of people and countries where the study was carried out are not stated.

\begin{tabular}{|c|c|c|c|c|}
\hline Type of Study & Country & No. of People & Health Effects & Reference \\
\hline Observational study & - & - & Menopausal diseases & [195] \\
\hline Observational study & Chile & 4348 & Chronic disease risk & [196] \\
\hline Meta-analysis & - & - & Metabolic syndrome & [197] \\
\hline Cohort study & Spain & 9408 men & Hypertension & [198] \\
\hline Cohort study & Italy & 13,597 & Hypertension & [199] \\
\hline Meta-analysis & - & 7000 & Hypertension & [200] \\
\hline $\begin{array}{c}\text { Randomized control } \\
\text { analysis (RCA) }\end{array}$ & - & 296 & Atherosclerosis & [201] \\
\hline RCA & Spain & 187 & Atherosclerosis & [202] \\
\hline Cohort study & $\begin{array}{l}10 \text { European } \\
\text { countries }\end{array}$ & 373,803 & Obesity & [203] \\
\hline Cohort study & $\begin{array}{l}8 \text { European } \\
\text { countries }\end{array}$ & 15,798 & Type 2 diabetes & [204] \\
\hline Cohort studies & - & - & Breast cancer & [205] \\
\hline Cohort study & United States & 51,529 & Prostate cancer & [206] \\
\hline Population study & Greece & 22,043 & Mortality & [207] \\
\hline Cohort study & - & 51,529 & Cognitive decline & [208] \\
\hline Cohort study & United Kingdom & 74,886 & Stroke & [209] \\
\hline RCA & $\begin{array}{l}5 \text { European } \\
\text { countries }\end{array}$ & 1294 & Osteoporosis & [210] \\
\hline Observational studies & - & - & Depression & [211] \\
\hline Cohort study & Spain & 22,786 & $\begin{array}{l}\text { Obesity, cardiovascular } \\
\text { disease, type } 2 \text { diabetes }\end{array}$ & [212] \\
\hline Observational study & Greece & 1,865 & Dementia & [213] \\
\hline Observational study & Italy & 480 & Osteoporosis & [214] \\
\hline RCA & Spain & 288 & Cardiovascular events & [215] \\
\hline Meta-analysis & - & 72 studies & Degenerative diseases & [216] \\
\hline Longitudal study & - & $3,316,633$ & Kidney stones & [217] \\
\hline Randomized control trial & Iran & 40 & Parkinson's disease & [155] \\
\hline Cross-sectional analysis & Germany & 340 & Cognitive performance & [218] \\
\hline Cross-sectional analysis & United Kingdom & 511 & Cognitive function & [219] \\
\hline $\begin{array}{l}\text { Systematic review and } \\
\text { meta-analysis }\end{array}$ & - & 41,963 & Cognitive function & [220] \\
\hline $\begin{array}{c}\text { Systematic review and } \\
\text { meta-analysis }\end{array}$ & - & 34,168 & Cognitive function & [221] \\
\hline Cohort study & Italy & 1936 & Sleep behavior & [222] \\
\hline Cohort study & Italy & 185 & Sleep behavior & [223] \\
\hline Cohort study & Italy & 1596 & Sleep behavior & [224] \\
\hline
\end{tabular}

\section{Consumers' Behavior, Market Opportunities and Trends}

Two of the major 21st century food policy challenges are the reduction of diet-related diseases and the improvement of environmental sustainability. Mediterranean dietary ingredients contain more energy, fiber, and nutrients per liter of water used; therefore, a shift towards the MD could reduce the consumptive water footprint by about $750 \mathrm{~L} /$ capita/day [225]. Consumers' perceptions about sustainability and food consumption has a highly significant effect on attitudes and personal and social norms related to waste reduction [226]. The most important drivers of food consumption are price, taste, convenience, and social and cultural factors and habits, in addition to the ethical aspects related to food [227]. The MD, as a plant-oriented dietary approach, appears to be an appropriate choice for humans and environmental sustainability because it reduces the environmental impact associated with the food value chain [228]. Moreover, the trend of decreasing adherence to the MD necessitates cross-disciplinary studies regarding its environmental, socioeconomic, cultural, and sustainability aspects, to preserve and transfer this sustainable dietary pattern to the next generations [229]. 
The MD may represent an ideal example of a sustainable diet and a part of a sustainability-oriented lifestyle; however, its adherence is significantly affected by consumers' income and education, and other socio-economic drivers [225]. Households with children and those with a higher degree of adherence to the MD have higher probabilities of buying complementary and healthy products, and increasing household size reduces the likelihood of buying niche products [230]. Similar results are presented in a study conducted in Italy by Carlos et al. [230], who identified three different consumer groups: (i) families with MD eating habits (26\%); (ii) families in transition who do not adhere to the MD (37\%); (iii) families with a less healthy diet. According to this definition, almost $26 \%$ of the Italian families adhered to the MD. Concerning Italian households' spending behavior, families with an older and more educated background are more likely to spend more on MD products compared to young and less educated consumers [231,232].

Because of its palatability and long-term sustainability, the MD combined with physical activity has shown promising results in terms of weight loss in individuals with obesity, in addition to similar beneficial effects in menopause-related obesity; the adherence to the MD in menopause reduced the risk of becoming obese, and improved the cardiometabolic profile and the menopausal symptoms [147]. Malnutrition (e.g., both obesity and undernutrition) is considered to be, in addition to climate change, a global threat, indicating an urgent need for a healthier and more sustainable food system [8]. Because $\mathrm{MD}$ adherence is affected by socio-economic factors, significant concerns have been raised about the abandonment of healthy diets and the shift towards Westernized and less sustainable eating patterns [233]. Moreover, recent research shows that the current Spanish diet is considerably different from the recommended Mediterranean diet, with three times more meat, dairy, and sugar product consumption, and one-third fewer fruits, vegetables, and cereals [234]. Another study of Spanish adults proved the direct association between the adherence to the MD and all of the physical, and most of the mental, health domains, including vitality and social and emotional functioning [235].

Many of the major post-modern chronic diseases, such as heart diseases, hypertension, obesity, and various types of cancer, have a dietary basis and are highly influenced by changes in dietary patterns due to changes in lifestyles. For example, from 1985 to 2005, adherence of young people to the MD decreased in southern Italy mainly due to the reduced consumption of olive oil [236]. To confront the recent decreased adherence to the MD and broaden the implementation of the MD outside the Mediterranean region requires focused communication activities and interventions in public health by governmental entities and stakeholders involved in policy making, the food industry, education sector, etc. [21].

The recent consumer trend for diversified diets suggests the consumption of wild greens may be fulfilled with the consumption of novel Mediterranean food products, such as wild halophytes or other wild edible species of the Mediterranean basin $[34,41,54,98,237,238]$. These wild species are considered a valuable genetic resource with the ability to adapt to severe conditions, such as soil and irrigation water salinity, thus facilitating the design and production process. Additionally, they provide significant functional and health beneficial properties that could be implemented in various food products, such as beverages, vegetable extracts, leafy greens, micro-encapsulated oils, food additives, and antimicrobial agents [41]. Furthermore, to combat the unfortunate trend of reduced adherence to the MD by the young Mediterranean population, a fruitful solution might be to improve dietary habits in the workplace, by altering eating patterns and applying diverse group and individual strategies, such as the installation of vending machines and the supplementation of workplace canteens with healthy food products [239]. In contrast, there is also an increasing trend of alternative dietary patterns, such as vegetarianism and veganism, in which higher MD adherence scores are observed compared to those of omnivores [240].

Another aspect to be considered about marketing trends and consumers' behavior is organic farming and its relevance to the MD. Regarding organic farming and the consumption of healthy food products, a recent study of Cypriot consumers revealed that $99 \%$ of respondents were aware of organic vegetables, but only $69 \%$ and $49 \%$ consumed or had knowledge of organically cultivated 
vegetables, respectively [241]. Moreover, consumers show great willingness to not only be properly informed via different means, but also to pay higher prices for organic vegetables, thus indicating a sustainable and profitable market opportunity. An emerging trend of healthy food consumption can also be seen in the recent opening of organic food restaurants in which consumers perceived the dishes to have good food quality, thus positively influencing price fairness and perceived value, leading to customer satisfaction and intention to return [242]. The trend for consumption of healthy food and sustainable cultivation has led niche market farmers of the World Wide Opportunities on Organic Farms movement (WWOOF) to open the farms to share their organic farming knowledge with guests, as a measure to attain the social, environmental, cultural and economic values that motivated their participation in the movement [243]. The positive exchange outcomes for the farmers were reduced uncertainty for their occupation, and enhanced equality and fairness, in addition to joint responsibility between the farmers and the citizens. In addition to the intangible benefits, organic food supply chains, when designed and implemented appropriately, are capable of delivering significant financial gains with higher sustainable development benefits, particularly when a sharing economy mechanism is applied [244].

\section{Conclusions and Future Directions}

The MD is highly recognized as a healthy diet with several extensions in aspects of daily life among inhabitants of the broader Mediterranean basin and other parts of the world. Recent evidence has shown a rapid transition to Western dietary habits with direct consequences for the health status of the general public, as reflected in the high incidence rates of chronic diseases. However, there is increasing interest among consumers for food safety, and healthy or functional food products, which has led to the rediscovery of traditional eating habits and the adherence to traditional diets such as the MD. Moreover, the interrelation of the MD with cultural, religious, and other life aspects is the driving force for the evolution of the traditional MD to a more modern approach to eating habits, thus allowing consumers to adapt to a healthy lifestyle. Considering these trends, the scientific community should further explore how these new alternative and modern "MedDiets" affect human health, to evidence the health effects with clinical studies and to reveal the protective mechanisms against various chronic diseases. Moreover, the agrifood industry must adapt to this new era by designing new and attractive food products that fulfill current consumer needs, while preserving the socioeconomic aspects of the MD and sustaining agrobiodiversity.

Author Contributions: E.C., M.C., F.D.G., S.A.P. contributed equally to the preparation of the draft manuscript and the review and editing of the final manuscript. All authors have read and agreed to the published version of the manuscript.

Funding: M. Carocho would like to thank the Portuguese Foundation for Science and Technology for funding the Centro de Investigação de Montanha (UIDB/00690/2020) and for his individual junior research contract (CEECIND/00831/2018). F. Di Gioia contribution was supported by the USDA National Institute of Food and Agriculture and Hatch Appropriations under Project \#PEN04723 and Accession \#1020664. S. A. Petropoulos contribution was supported by the General Secretariat for Research and Technology of Greece and PRIMA foundation under the project Valuefarm (Prima2019-11).

Acknowledgments: The authors wish to thank Di Gioia Michele, Larosa Anna, Rossella Carone, Losito Mario and Giuseppe Lops for their assistance in the collection of local vegetables and wild edible greens and/or the preparation of rural dishes typical of the traditional Mediterranean diet used for the pictures presented in this manuscript.

Conflicts of Interest: The authors declare no conflict of interest.

\section{References}

1. Cena, H.; Calder, P.C. Defining a healthy diet: Evidence for the role of contemporary dietary patterns in health and disease. Nutrients 2020, 12, 334. [CrossRef] [PubMed]

2. Murakami, K.; Livingstone, M.B.E.; Fujiwara, A.; Sasaki, S. Breakfast in Japan: Findings from the 2012 national health and nutrition survey. Nutrients 2018, 10, 1551. [CrossRef] [PubMed]

3. Fernstrom, J.D. Effects of the diet on brain function. Acta Astronaut. 1981, 8, 1035-1042. [CrossRef] 
4. Rodríguez-Martín, C.; Garcia-Ortiz, L.; Rodriguez-Sanchez, E.; Martin-Cantera, C.; Soriano-Cano, A.; Arietaleanizbeaskoa, M.S.; Magdalena-Belio, J.F.; Menendez-Suarez, M.; Maderuelo-Fernandez, J.A.; Lugones-Sanchez, C.; et al. The relationship of the atlantic diet with cardiovascular risk factors and markers of arterial stiffness in adults without cardiovascular disease. Nutrients 2019, 11, 742. [CrossRef]

5. Montagnese, C.; Santarpia, L.; Buonifacio, M.; Nardelli, A.; Caldara, A.R.; Silvestri, E.; Contaldo, F.; Pasanisi, F. European food-based dietary guidelines: A comparison and update. Nutrition 2015, 31, 908-915. [CrossRef]

6. Lorgeril, M. De Mediterranean Diet and Cardiovascular Disease: Historical Perspective and Latest Evidence. Curr. Atheroscler. Rep. 2013, 15, 4-8. [CrossRef]

7. Trichopoulou, A.; Bamia, C.; Trichopoulos, D. Anatomy of health effects of Mediterranean diet: Greek EPIC prospective cohort study. BMJ 2009, 339, 26-28. [CrossRef]

8. Hidalgo-Mora, J.J.; García-Vigara, A.; Sánchez-Sánchez, M.L.; García-Pérez, M.Á.; Tarín, J.; Cano, A. The Mediterranean diet: A historical perspective on food for health. Maturitas 2020, 132, 65-69. [CrossRef]

9. Hatzis, C.M.; Papandreou, C.; Patelarou, E.; Vardavas, C.I.; Kimioni, E.; Sifaki-Pistolla, D.; Vergetaki, A.; Kafatos, A.G. A 50-year follow-up of the Seven Countries Study: Prevalence of cardiovascular risk factors, food and nutrient intakes among Cretans. Hormones 2013, 12, 379-385. [CrossRef]

10. Mazzocchi, A.; Leone, L.; Agostoni, C.; Pali-Schöll, I. The secrets of the mediterranean diet. Does [only] olive oil matter? Nutrients 2019, 11, 2941. [CrossRef]

11. DellaGreca, M. Nutraceuticals and Mediterranean Diet. Med. Aromat. Plants 2012, 1, 1-3. [CrossRef]

12. Tosti, V.; Bertozzi, B.; Fontana, L. Health Benefits of the Mediterranean Diet: Metabolic and Molecular Mechanisms. J. Gerontol. Ser. A Biol. Sci. Med. Sci. 2018, 73, 318-326. [CrossRef] [PubMed]

13. Foscolou, A.; D'Cunha, N.M.; Naumovski, N.; Tyrovolas, S.; Chrysohoou, C.; Rallidis, L.; Polychronopoulos, E.; Matalas, A.L.; Sidossis, L.S.; Panagiotakos, D. The association between the level of adherence to the Mediterranean diet and successful aging: An analysis of the ATTICA and MEDIS (MEDiterranean Islands Study) epidemiological studies. Arch. Gerontol. Geriatr. 2020, 89, 104044. [CrossRef] [PubMed]

14. Saulle, R.; La Torre, G. The Mediterranean Diet, recognized by UNESCO as a cultural heritage of humanity. Ital. J. Public Health 2010, 7, 414-415.

15. Keys, A.; Mienotti, A.; Karvonen, M.J.; Aravanis, C.; Blackburn, H.; Buzina, R.; Djordjevic, B.S.; Dontas, A.S.; Fidanza, F.; Keys, M.H.; et al. The diet and 15-year death rate in the seven countries study. Am. J. Epidemiol. 1986, 124, 903-915. [CrossRef]

16. Nestle, M. Mediterranean diets: Historical and research overview. Am. J. Clin. Nutr. 1995, 61, 1313S-1320S. [CrossRef]

17. Davis, C.; Bryan, J.; Hodgson, J.; Murphy, K. Definition of the mediterranean diet: A literature review. Nutrients 2015, 7, 9139-9153. [CrossRef]

18. Varela-Moreiras, G.; Ávila, J.M.; Cuadrado, C.; del Pozo, S.; Ruiz, E.; Moreiras, O. Evaluation of food consumption and dietary patterns in Spain by the Food Consumption Survey: Updated information. Eur. J. Clin. Nutr. 2010, 64, S37-S43. [CrossRef]

19. Karamanos, B.; Thanopoulou, A.; Angelico, F.; Assaad-Khalil,S.; Barbato, A.; Del Ben, M.; Dimitrijevic-Sreckovic, V.; Djordjevic, P.; Gallotti, C.; Katsilambros, N.; et al. Nutritional habits in the Mediterranean Basin. The macronutrient composition of diet and its relation with the tradiational Mediterranean diet. Multi-centre study of the Mediterranean Group for the study of diabetes (MGSD). Eur. J. Clin. Nutr. 2002, 56, 983-991. [CrossRef]

20. Pfeilstetter, R. Heritage entrepreneurship. Agency-driven promotion of the Mediterranean diet in Spain. Int. J. Herit. Stud. 2015, 21, 215-231. [CrossRef]

21. Murphy, K.J.; Parletta, N. Implementing a Mediterranean-Style Diet outside the Mediterranean Region. Curr. Atheroscler. Rep. 2018, 20, 1-10. [CrossRef] [PubMed]

22. Bach-Faig, A.; Berry, E.M.; Lairon, D.; Reguant, J.; Trichopoulou, A.; Dernini, S.; Medina, F.X.; Battino, M.; Belahsen, R.; Miranda, G.; et al. Mediterranean diet pyramid today. Science and cultural updates. Public Health Nutr. 2011, 14, 2274-2284. [CrossRef] [PubMed]

23. D'Alessandro, A.; Lampignano, L.; De Pergola, G. Mediterranean diet pyramid: A proposal for Italian people. a systematic review of prospective studies to derive serving sizes. Nutrients 2019, 11, 1296. [CrossRef]

24. Willett, W.C.; Sacks, F.; Trichopoulou, A.; Drescher, G.; Ferro-Luzzi, A.; Helsing, E.; Trichopoulos, D. Mediterranean diet pyramid: A cultural model for healthy eating. Am. J. Clin. Nutr. 1995, 61, 1402S-1406S. [CrossRef] [PubMed] 
25. Lăcătușu, C.M.; Grigorescu, E.D.; Floria, M.; Onofriescu, A.; Mihai, B.M. The mediterranean diet: From an environment-driven food culture to an emerging medical prescription. Int. J. Environ. Res. Public Health 2019, 16, 942. [CrossRef] [PubMed]

26. Mattson, F.H.; Grundy, S.M. Comparison of effects of dietary saturated, mono- unsaturated, and polyunsaturated fatty acids on plasma lipids and lipoproteins in man. J. Lipid Res. 1985, 26, $194-202$. [PubMed]

27. Rus, A.; Molina, F.; Martínez-Ramírez, M.J.; Aguilar-Ferrándiz, M.E.; Carmona, R.; Moral, M.L. Del Effects of olive oil consumption on cardiovascular risk factors in patients with fibromyalgia. Nutrients 2020, $12,918$. [CrossRef]

28. Zamora-Zamora, F.; Martínez-Galiano, J.M.; Gaforio, J.J.; Delgado-Rodríguez, M. Effects of olive oil on blood pressure: A systematic review and meta-analysis. Grasas Aceites 2018, 69. [CrossRef]

29. Godos, J.; Vitale, M.; Micek, A.; Ray, S.; Martini, D.; Del Rio, D.; Riccardi, G.; Galvano, F.; Grosso, G. Dietary polyphenol intake, blood pressure, and hypertension: A systematic review and meta-analysis of observational studies. Antioxidants 2019, 8, 152. [CrossRef]

30. Grosso, G.; Micek, A.; Godos, J.; Pajak, A.; Sciacca, S.; Galvano, F.; Giovannucci, E.L. Dietary Flavonoid and Lignan Intake and Mortality in Prospective Cohort Studies: Systematic Review and Dose-Response Meta-Analysis. Am. J. Epidemiol. 2017, 185, 1304-1316. [CrossRef]

31. Xu, H.; Luo, J.; Huang, J.; Wen, Q. Flavonoids intake and risk of type 2 diabetes mellitus: A meta-analysis of prospective cohort studies. Medicine 2018, 97, 1-7. [CrossRef]

32. Grosso, G.; Godos, J.; Lamuela-Raventos, R.; Ray, S.; Micek, A.; Pajak, A.; Sciacca, S.; D’Orazio, N.; Del Rio, D.; Galvano, F. A comprehensive meta-analysis on dietary flavonoid and lignan intake and cancer risk: Level of evidence and limitations. Mol. Nutr. Food Res. 2017, 61, 1600930. [CrossRef] [PubMed]

33. Ferro-Luzzi, A.; James, W.P.T.; Kafatos, A. The high-fat Greek diet: A recipe for all? Eur. J. Clin. Nutr. 2002, 56, 796-809. [CrossRef] [PubMed]

34. Corrêa, R.C.G.; Di Gioia, F.; Ferreira, I.C.F.R.; Petropoulos, S.A. Wild greens used in the Mediterranean diet. In The Mediterranean Diet: An Evidence-Based Approach; Preedy, V., Watson, R., Eds.; Academic Press: London, UK, 2020; pp. 209-228. ISBN 9788578110796.

35. Motti, R.; Bonanomi, G.; Lanzotti, V.; Sacchi, R. The Contribution of Wild Edible Plants to the Mediterranean Diet: An Ethnobotanical Case Study along the Coast of Campania (Southern Italy). Econ. Bot. 2020, 74, 249-272. [CrossRef]

36. Benhammou, S.; Heras-González, L.; Ibáñez-Peinado, D.; Barceló, C.; Hamdan, M.; Rivas, A.; Mariscal-Arcas, M.; Olea-Serrano, F.; Monteagudo, C. Comparison of Mediterranean diet compliance between European and non-European populations in the Mediterranean basin. Appetite 2016, 107, 521-526. [CrossRef] [PubMed]

37. FAO. The State of the World's Biodiversity for Food and Agriculture. In The State of the World's Biodiversity for Food and Agriculture; Pilling, D., Bélanger, J., Eds.; FAO: Rome, Italy, 2019; 572p, ISBN 9789251312704.

38. Hadjichambis, A.C.; Paraskeva-Hadjichambi, D.; Della, A.; Elena Giusti, M.; De Pasquale, C.; Lenzarini, C.; Censorii, E.; Reyes Gonzales-Tejero, M.; Patricia Sanchez-Rojas, C.; Ramiro-Gutierrez, J.M.; et al. Wild and semi-domesticated food plant consumption in seven circum-Mediterranean areas. Int. J. Food Sci. Nutr. 2008, 59, 383-414. [CrossRef]

39. De Cortes Sánchez-Mata, M.; Tardío, J. Mediterranean Wild Edible Plants; Springer: New York, NY, USA, 2016; ISBN 978-1-4939-3327-3.

40. Petropoulos, S.; Fernandes, A.; Barros, L.; Ferreira, I. A comparison of the phenolic profile and antioxidant activity of different Cichorium spinosum L. ecotypes. J. Sci. Food Agric. 2017, 98, 183-189. [CrossRef]

41. Petropoulos, S.A.A.; Karkanis, A.; Martins, N.; Ferreira, I.C.F.R. Edible halophytes of the Mediterranean basin: Potential candidates for novel food products. Trends Food Sci. Technol. 2018, 74, 69-84. [CrossRef]

42. Petropoulos, S.; Ntatsi, G.; Levizou, E.; Barros, L.; Ferreira, I. Nutritional profile and chemical composition of Cichorium spinosum ecotypes. LWT Food Sci. Technol. 2016, 73, 95-101. [CrossRef]

43. Elia, A.; Santamaria, P. Biodiversity in vegetable crops, a heritage to save: The case of Puglia region. Ital. J. Agron. 2013, 8, 21-34. [CrossRef]

44. Heinrich, M.; Müller, W.E.; Galli, C. Local Mediterranean Food Plants and Nutraceuticals; Karger: Basel, Switzerland, 2006; ISBN 978-3-8055-8124-0. 
45. Sánchez-Mata, M.C.; Loera, R.D.C.; Morales, P.; Fernández-Ruiz, V.; Cámara, M.; Marqués, C.D.; Pardo-de-Santayana, M.; Tardío, J.; Cabrera Loera, R.D.; Morales, P.; et al. Wild vegetables of the Mediterranean area as valuable sources of bioactive compounds. Genet. Resour. Crop Evol. 2012, 59, 431-443. [CrossRef]

46. Boari, F.; Cefola, M.; Di Gioia, F.; Pace, B.; Serio, F.; Cantore, V. Effect of cooking methods on antioxidant activity and nitrate content of selected wild Mediterranean plants. Int. J. Food Sci. Nutr. 2013, 64, 870-876. [CrossRef] [PubMed]

47. Bonasia, A.; Conversa, G.; Lazzizera, C.; Loizzo, P.; Gambacorta, G.; Elia, A. Evaluation of Garlic Landraces from Foggia Province (Puglia Region; Italy). Foods 2020, 9, 850. [CrossRef] [PubMed]

48. Petropoulos, S.A.; Fernandes, Â.; Ntatsi, G.; Petrotos, K.; Barros, L.; Ferreira, I.C.F.R. Nutritional value, chemical characterization and bulb morphology of Greek Garlic landraces. Molecules 2018, 23, 319. [CrossRef] [PubMed]

49. Petropoulos, S.A.S.; Fernandes, Â.; Barros, L.; Ferreira, I.C.F.R.; Ntatsi, G. Morphological, nutritional and chemical description of "Vatikiotiko", an onion local landrace from Greece. Food Chem. 2015, 182, 156-163. [CrossRef]

50. Siracusa, L.; Avola, G.; Patanè, C.; Riggi, E.; Ruberto, G. Re-evaluation of traditional mediterranean foods. the local landraces of "cipolla di giarratana" (Allium cepa L.) and long-storage tomato (Lycopersicon esculentum L.): Quality traits and polyphenol content. J. Sci. Food Agric. 2013, 93, 3512-3519. [CrossRef]

51. Riggi, E.; Avola, G.; Siracusa, L.; Ruberto, G. Flavonol content and biometrical traits as a tool for the characterization of "cipolla di Giarratana": A traditional Sicilian onion landrace. Food Chem. 2013, 140, 810-816. [CrossRef]

52. Marrelli, M.; Statti, G.; Conforti, F. A review of biologically active natural products from Mediterranean wild edible plants: Benefits in the treatment of obesity and its related disorders. Molecules 2020, 25, 649. [CrossRef]

53. Petropoulos, S.A.; Barros, L.; Ferreira, I.C.F.R. Editorial: Rediscovering Local Landraces: Shaping Horticulture for the Future. Front. Plant Sci. 2019, 10, 1-2. [CrossRef]

54. Conversa, G.; Lazzizera, C.; Bonasia, A.; Cifarelli, S.; Losavio, F.; Sonnante, G.; Elia, A. Exploring on-farm agro-biodiversity: A study case of vegetable landraces from Puglia region (Italy). Biodivers. Conserv. 2020, 29, 747-770. [CrossRef]

55. Correa, R.C.G.; Di Gioia, F.; Ferreira, I.; SA, P. Halophytes for Future Horticulture: The Case of Small-Scale Farming in the Mediterranean Basin. In Halophytes for Future Horticulture: From Molecules to Ecosystems towards Biosaline Agriculture; Grigore, M.N., Ed.; Springer Nature Switzerland AG: Cham, Switzerland, 2020; pp. 1-28, ISBN 9783030178543.

56. Petropoulos, S.A.; Sampaio, S.L.; Di Gioia, F.; Tzortzakis, N.; Rouphael, Y.; Kyriacou, M.C.; Ferreira, I. Grown to be Blue-Antioxidant Properties and Health Effects of Colored Vegetables. Part I: Root Vegetables. Antioxidants 2019, 8, 617. [CrossRef]

57. Di Gioia, F.; Tzortzakis, N.; Rouphael, Y.; Kyriacou, M.C.; Sampaio, S.L.; Ferreira, I.C.F.R.; Petropoulos, S.A. Grown to be blue-Antioxidant properties and health effects of colored vegetables. Part II: Leafy, fruit, and other vegetables. Antioxidants 2020, 9, 97. [CrossRef] [PubMed]

58. D'Antuono, I.; Di Gioia, F.; Linsalata, V.; Rosskopf, E.N.; Cardinali, A. Impact on health of artichoke and cardoon bioactive compounds: Content, bioaccessibility, bioavailability, and bioactivity. In Phytochemicals in Vegetables: A Valuable Source of Bioactive Compounds; Petropoulos, S.A., Ferreira, I.C.F.R., Barros, L., Eds.; Bentham Science Publishers Ltd.: Sharjah, UAE, 2018; 373p.

59. Pavan, S.; Curci, P.L.; Zuluaga, D.L.; Blanco, E.; Sonnante, G. Genotyping-by-sequencing highlights patterns of genetic structure and domestication in artichoke and cardoon. PLoS ONE 2018, 13. [CrossRef] [PubMed]

60. Mauro, R.; Portis, E.; Acquadro, A.; Lombardo, S.; Mauromicale, G.; Lanteri, S. Genetic diversity of globe artichoke landraces from Sicilian small-holdings: Implications for evolution and domestication of the species. Conserv. Genet. 2009, 10, 431-440. [CrossRef]

61. Petropoulos, S.A.; Pereira, C.; Ntatsi, G.; Danalatos, N.; Barros, L.; Ferreira, I.C.F.R. Nutritional value and chemical composition of Greek artichoke genotypes. Food Chem. 2017. [CrossRef]

62. Petropoulos, S.A.; Pereira, C.; Tzortzakis, N.; Barros, L.; Ferreira, I.C.F.R. Nutritional value and bioactive compounds characterization of plant parts from Cynara cardunculus L. (Asteraceae) cultivated in central Greece. Front. Plant Sci. 2018, 9, 1-12. [CrossRef] 
63. Petropoulos, S.; Fernandes, Â.; Pereira, C.; Tzortzakis, N.; Vaz, J.; Soković, M.; Barros, L.; Ferreira, I.C.F.R. Bioactivities, chemical composition and nutritional value of Cynara cardunculus L. seeds. Food Chem. 2019, 289, 404-412. [CrossRef]

64. Scarano, A.; Gerardi, C.; D'Amico, L.; Accogli, R.; Santino, A. Phytochemical analysis and antioxidant properties in colored tiggiano carrots. Agriculture 2018, 8, 102. [CrossRef]

65. Gracia, A.; Sánchez, A.M.; Jurado, F.; Mallor, C. Making use of sustainable local plant genetic resources: Would consumers support the recovery of a traditional purple carrot? Sustainability 2020, 12, 6549. [CrossRef]

66. Cefola, M.; Pace, B.; Renna, M.; Santamaria, P.; Signore, A.; Serio, F. Compositional analysis and antioxidant profile of yellow, orange and purple polignano carrots. Ital. J. Food Sci. 2012, 24, 284-291.

67. Innocenti, M.; Gallori, S.; Giaccherini, C.; Ieri, F.; Vincieri, F.F.; Mulinacci, N. Evaluation of the phenolic content in the aerial parts of different varieties of Cichorium intybus L. J. Agric. Food Chem. 2005, 53, 6497-6502. [CrossRef] [PubMed]

68. Missio, C.J.; Rivera, A.; Figàs, M.R.; Casanova, C.; Camí, B.; Soler, S.; Simó, J. A comparison of landraces vs. modern varieties of lettuce in organic farming during the winter in the Mediterranean area: An approach considering the viewpoints of breeders, consumers and farmers. Front. Plant Sci. 2018, 9, 1-15. [CrossRef] [PubMed]

69. Branca, F.; Chiarenza, G.L.; Cavallaro, C.; Gu, H.; Zhao, Z.; Tribulato, A. Diversity of Sicilian broccoli (Brassica oleracea var. italica) and cauliflower (Brassica oleracea var. botrytis) landraces and their distinctive bio-morphological, antioxidant, and genetic traits. Genet. Resour. Crop Evol. 2018, 65, 485-502. [CrossRef]

70. Lotti, C.; Iovieno, P.; Centomani, I.; Marcotrigiano, A.R.; Fanelli, V.; Mimiola, G.; Summo, C.; Pavan, S.; Ricciardi, L. Genetic, bio-agronomic, and nutritional characterization of kale (Brassica oleracea L. var. acephala) diversity in Apulia, Southern Italy. Diversity 2018, 10, 25. [CrossRef]

71. Petropoulos, S.A.; Di Gioia, F.; Polyzos, N.; Tzortzakis, N. Natural antioxidants, health effects and bioactive properties of wild Allium species. Curr. Pharm. Des. 2020, 26, 1816-1837. [CrossRef]

72. Petropoulos, S.; Fernandes, Â.; Barros, L.; Ciric, A.; Sokovic, M.; Ferreira, I.C.F.R. Antimicrobial and antioxidant properties of various Greek garlic genotypes. Food Chem. 2018, 245, 7-12. [CrossRef]

73. Avgeri, I.; Zeliou, K.; Petropoulos, S.A.; Bebeli, P.J.; Papasotiropoulos, V.; Lamari, F.N. Variability in bulb organosulfur compounds, sugars, phenolics, and pyruvate among greek garlic genotypes: Association with antioxidant properties. Antioxidants 2020, 9, 967. [CrossRef]

74. Mallor, C.; Balcells, M.; Mallor, F.; Sales, E. Genetic variation for bulb size, soluble solids content and pungency in the Spanish sweet onion variety Fuentes de Ebro. Response to selection for low pungency. Plant Breed. 2011, 130, 55-59. [CrossRef]

75. Petropoulos, S.A.; Ntatsi, G.; Fernandes, Â.; Barros, L.; Barreira, J.C.M.; Ferreira, I.C.F.R.; Antoniadis, V. Long-term storage effect on chemical composition, nutritional value and quality of Greek onion landrace "Vatikiotiko". Food Chem. 2016, 201, 168-176. [CrossRef]

76. Ricciardi, L.; Mazzeo, R.; Marcotrigiano, A.R.; Rainaldi, G.; Iovieno, P.; Zonno, V.; Pavan, S.; Lotti, C. Assessment of genetic diversity of the "acquaviva red onion" (Allium cepa L.) apulian landrace. Plants 2020, 9, 260. [CrossRef]

77. Oliveira, H.R.; Tomás, D.; Silva, M.; Lopes, S.; Viegas, W.; Veloso, M.M. Genetic diversity and population structure in Vicia faba L. landraces and wild related species assessed by nuclear SSRs. PLoS ONE 2016, 11, 1-18. [CrossRef] [PubMed]

78. Lioi, L.; Zuluaga, D.L.; Pavan, S.; Sonnante, G. Genotyping-by-sequencing reveals molecular genetic diversity in Italian common bean landraces. Diversity 2019, 11, 154. [CrossRef]

79. Lioi, L.; Morgese, A.; Cifarelli, S.; Sonnante, G. Germplasm collection, genetic diversity and on-farm conservation of cowpea [Vigna unguiculata (L.) Walp.] landraces from Apulia region (southern Italy). Genet. Resour. Crop Evol. 2019, 66, 165-175. [CrossRef]

80. Hammer, K.; Hanelt, P.; Perrino, P. Carosello and the taxonomy of Cucumis melo L. especially of its vegetable races. Die Kult. 1986, 34, 249-259. [CrossRef]

81. Paris, H.; Janick, J. Early evidence for the culinary use of squash flowers in Italy. Chron. Horticult. 2005, 45, 20-21.

82. Staub, J.E.; López-Sesé, A.I.; Fanourakis, N. Diversity among melon landraces (Cucumis melo L.) from Greece and their genetic relationships with other melon germplasm of diverse origins. Euphytica 2004, 136, 151-166. [CrossRef] 
83. Formisano, G.; Roig, C.; Esteras, C.; Ercolano, M.R.; Nuez, F.; Monforte, A.J.; Picó, M.B. Genetic diversity of Spanish Cucurbita pepo landraces: An unexploited resource for summer squash breeding. Genet. Resour. Crop Evol. 2012, 59, 1169-1184. [CrossRef]

84. Paris, H.S.; Lebeda, A.; Křistkova, E.; Andres, T.C.; Nee, M.H. Parallel Evolution Under Domestication and Phenotypic Differentiation of the Cultivated Subspecies of Cucurbita pepo (Cucurbitaceae). Econ. Bot. 2012, 66, 71-90. [CrossRef]

85. Carillo, P.; Kyriacou, M.C.; El-Nakhel, C.; Pannico, A.; dell'Aversana, E.; D'Amelia, L.; Colla, G.; Caruso, G.; De Pascale, S.; Rouphael, Y. Sensory and functional quality characterization of protected designation of origin 'Piennolo del Vesuvio' cherry tomato landraces from Campania-Italy. Food Chem. 2019, 292, 166-175. [CrossRef]

86. Conesa, M.; Fullana-Pericàs, M.; Granell, A.; Galmés, J. Mediterranean Long Shelf-Life Landraces: An Untapped Genetic Resource for Tomato Improvement. Front. Plant Sci. 2020, 10, 1-21. [CrossRef]

87. Figàs, M.R.; Prohens, J.; Raigón, M.D.; Pereira-Dias, L.; Casanova, C.; García-Martínez, M.D.; Rosa, E.; Soler, E.; Plazas, M.; Soler, S. Insights into the adaptation to greenhouse cultivation of the traditional mediterranean long shelf-life tomato carrying the alc mutation: A multi-trait comparison of landraces, selections, and hybrids in open field and greenhouse. Front. Plant Sci. 2018, 871, 1-16. [CrossRef] [PubMed]

88. Renna, M.; Durante, M.; Gonnella, M.; Buttaro, D.; D'Imperio, M.; Mita, G.; Serio, F. Quality and nutritional evaluation of regina tomato, a traditional long-storage landrace of puglia (Southern Italy). Agriculture 2018, 8, 83. [CrossRef]

89. Di Gioia, F.; Serio, F.; Buttaro, D.; Ayala, O.; Santamaria, P. Influence of rootstock on vegetative growth, fruit yield and quality in "Cuore di Bue", an heirloom tomato. J. Hortic. Sci. Biotechnol. 2010, 85, 477-482. [CrossRef]

90. Figás, M.R.; Prohens, J.; Díez, M.J.; Soler, S. Recovering and enhancing the local tomatoes of the Vall d'Albaida, an inland district in the region of València (Spain). Landraces 2019, 4, 24-27.

91. Pereira-Dias, L.; Vilanova, S.; Fita, A.; Prohens, J.; Rodríguez-Burruezo, A. Genetic diversity, population structure, and relationships in a collection of pepper (Capsicum spp.) landraces from the Spanish centre of diversity revealed by genotyping-by-sequencing (GBS). Hortic. Res. 2019, 6. [CrossRef]

92. Gramazio, P.; Chatziefstratiou, E.; Petropoulos, C.; Chioti, V.; Mylona, P.; Kapotis, G.; Vilanova, S.; Prohens, J.; Papasotiropoulos, V. Multi-level characterization of eggplant accessions from Greek islands and the mainland contributes to the enhancement and conservation of this germplasm and reveals a large diversity and signatures of differentiation between both origins. Agronomy 2019, 9, 887. [CrossRef]

93. Bonasia, A.; Conversa, G.; Lazzizera, C.; Elia, A. Post-harvest performance of ready-to-eat wild rocket salad as affected by growing period, soilless cultivation system and genotype. Postharvest Biol. Technol. 2019, 156, 110909. [CrossRef]

94. Di Gioia, F.; Avato, P.; Serio, F.; Argentieri, M.P. Glucosinolate profile of Eruca sativa, Diplotaxis tenuifolia and Diplotaxis erucoides grown in soil and soilless systems. J. Food Compos. Anal. 2018, 69, 197-204. [CrossRef]

95. Guijarro-Real, C.; Rodríguez-Burruezo, A.; Fita, A. Volatile profile of wall rocket baby-leaves (Diplotaxis erucoides) grown under greenhouse: Main compounds and genotype diversity. Agronomy 2020, 10, 802. [CrossRef]

96. Di Gioia, F.; Santamaria, P. Ai mercati piace la cima di rapa pugliese ortagio "antico". Ortofrutta Ital. 2009, 2, 102-106.

97. Mazzeo, R.; Morgese, A.; Sonnante, G.; Zuluaga, D.L.; Pavan, S.; Ricciardi, L.; Lotti, C. Genetic Diversity in broccoli rabe (Brassica rapa L. subsp. sylvestris (L.) Janch.) from Southern Italy. Sci. Hortic. 2019, 253, 140-146.

98. Petropoulos, S.A.; Fernandes, Â.; Tzortzakis, N.; Sokovic, M.; Ciric, A.; Barros, L.; Ferreira, I.C.F.R. Bioactive compounds content and antimicrobial activities of wild edible Asteraceae species of the Mediterranean flora under commercial cultivation conditions. Food Res. Int. 2019, 119, 859-868. [CrossRef] [PubMed]

99. Petropoulos, S.A.; Fernandes, Â.; Dias, M.I.; Pereira, C.; Calhelha, R.; Di Gioia, F.; Tzortzakis, N.; Ivanov, M.; Sokovic, M.; Barros, L.; et al. Wild and cultivated Centaurea raphanina subsp. mixta: A valuable source of bioactive compounds. Antioxidants 2020, 9, 314.

100. Petropoulos, S.A.; Fernandes, Â.; Dias, M.I.; Pereira, C.; Calhelha, R.C.; Ivanov, M.; Sokovic, M.D.; Ferreira, I.C.F.R.; Barros, L. The Effect of Nitrogen Fertigation and Harvesting Time on Plant Growth and Chemical Composition of Centaurea raphanina subsp. mixta (DC.) Runemark. Molecules 2020, 25, 3175. [CrossRef] 
101. Petropoulos, S.A.; Fernandes, Â.; Dias, M.I.; Pereira, C.; Calhelha, R.C.; Chrysargyris, A.; Tzortzakis, N.; Ivanov, M.; Sokovic, M.D.; Barros, L.; et al. Chemical composition and plant growth of Centaurea raphanina subsp. mixta plants cultivated under saline conditions. Molecules 2020, 25, 2204.

102. Petropoulos, S.; Levizou, E.; Ntatsi, G.; Fernandes, Â.; Petrotos, K.; Akoumianakis, K.; Barros, L.; Ferreira, I. Salinity effect on nutritional value, chemical composition and bioactive compounds content of Cichorium spinosum L. Food Chem. 2017, 214, 129-136. [CrossRef]

103. Petropoulos, S.; Karkanis, A.; Fernandes, Â.; Barros, L.; Ferreira, I.C.F.R.; Ntatsi, G.; Petrotos, K.; Lykas, C.; Khah, E. Chemical composition and yield of six genotypes of common purslane (Portulaca oleracea L.): An alternative source of omega-3 fatty acids. Plant Foods Hum. Nutr. 2015, 70, 420-426. [CrossRef]

104. Petropoulos, S.; Karkanis, A.; Martins, N.; Ferreira, I.C.F.R. Phytochemical composition and bioactive compounds of common purslane (Portulaca oleracea L.) as affected by crop management practices. Trends Food Sci. Technol. 2016, 55, 1-10. [CrossRef]

105. Tarsitano, E.; Calvano, G.; Cavalcanti, E. The Mediterranean Way a model to achieve the 2030 Agenda Sustainable Development Goals (SDGs). J. Sustain. Dev. 2019, 12, 108. [CrossRef]

106. Burlingame, B.; Dernini, S. Sustainable Diets and Biodiversity. Directions and Solutions for Policy, Research and Action; Burlingame, B., Dernini, S., Eds.; FAO: Rome, Italy, 2010; ISBN 9789251072882.

107. Trautwein, E.A.; McKay, S. The role of specific components of a plant-based diet in management of dyslipidemia and the impact on cardiovascular risk. Nutrients 2020, 12, 2671. [CrossRef]

108. Benvenuti, S.; Maggini, R.; Pardossi, A. Agronomic, Nutraceutical, and Organoleptic Performances of Wild Herbs of Ethnobotanical Tradition. Int. J. Veg. Sci. 2017, 23, 270-281. [CrossRef]

109. Johns, T.; Powell, B.; Maundu, P.; Eyzaguirre, P.B. Agricultural biodiversity as a link between traditional food systems and contemporary development, social integrity and ecological health. J. Sci. Food Agric. 2013, 93, 3433-3442. [CrossRef] [PubMed]

110. Zimmerer, K.S.; Vanek, S.J. Toward the integrated framework analysis of linkages among agrobiodiversity, livelihood diversification, ecological systems, and sustainability amid global change. Land 2016, 5, 10. [CrossRef]

111. Morales, P.; Ferreira, I.C.F.R.; Carvalho, A.M.; Sánchez-Mata, M.C.; Cámara, M.; Fernández-Ruiz, V.; Pardo-de-Santayana, M.; Tardío, J. Mediterranean non-cultivated vegetables as dietary sources of compounds with antioxidant and biological activity. LWT Food Sci. Technol. 2014, 55, 389-396. [CrossRef]

112. Guiomar, N.; Godinho, S.; Pinto-Correia, T.; Almeida, M.; Bartolini, F.; Bezák, P.; Biró, M.; Bjørkhaug, H.; Bojnec, S.; Brunori, G.; et al. Typology and distribution of small farms in Europe: Towards a better picture. Land Use Policy 2018, 75, 784-798. [CrossRef]

113. Petropoulos, S.; Fernandes, Â.; Vasileios, A.; Ntatsi, G.; Barros, L.; Ferreira, I. Chemical composition and antioxidant activity of Cichorium spinosum L. leaves in relation to developmental stage. Food Chem. 2018, 239, 946-952. [CrossRef]

114. Petropoulos, S.; Fernandes, Â.; Karkanis, A.; Ntatsi, G.; Barros, L.; Ferreira, I. Successive harvesting affects yield, chemical composition and antioxidant activity of Cichorium spinosum L. Food Chem. 2017, 237, 83-90. [CrossRef]

115. Petropoulos, S.A.; Fernandes, Â.; Dias, M.I.; Vasilakoglou, I.B.; Petrotos, K.; Barros, L.; Ferreira, I.C.F.R. Nutritional value, chemical composition and cytotoxic properties of common purslane (Portulaca oleracea L.) in relation to harvesting stage and plant part. Antioxidants 2019, 8, 293. [CrossRef]

116. Bonaccio, M.; Bes-Rastrollo, M.; de Gaetano, G.; Iacoviello, L. Challenges to the Mediterranean diet at a time of economic crisis. Nutr. Metab. Cardiovasc. Dis. 2016, 26, 1057-1063. [CrossRef]

117. Panagiotakos, D.B.; Pitsavos, C.; Chrysohoou, C.; Vlismas, K.; Skoumas, Y.; Palliou, K.; Stefanadis, C. The effect of clinical characteristics and dietary habits on the relationship between education status and 5-year incidence of cardiovascular disease: The ATTICA study. Eur. J. Nutr. 2008, 47, 258-265. [CrossRef]

118. Katsarou, A.; Tyrovolas, S.; Psaltopoulou, T.; Zeimbekis, A.; Tsakountakis, N.; Bountziouka, V.; Gotsis, E.; Metallinos, G.; Polychronopoulos, E.; Lionis, C.; et al. Socio-economic status, place of residence and dietary habits among the elderly: The Mediterranean islands study. Public Health Nutr. 2010, 13, 1614-1621. [CrossRef] [PubMed]

119. Panagiotakos, D.B.; Pitsavos, C.; Chrysohoou, C.; Vlismas, K.; Skoumas, Y.; Palliou, K.; Stefanadis, C. Dietary habits mediate the relationship between socio-economic status and CVD factors among healthy adults: The ATTICA study. Public Health Nutr. 2008, 11, 1342-1349. [CrossRef] [PubMed] 
120. Bonasia, A.; Lazzizera, C.; Elia, A.; Conversa, G. Nutritional, biophysical and physiological characteristics of wild rocket genotypes as affected by soilless cultivation system, salinity level of nutrient solution and growing period. Front. Plant Sci. 2017, 8, 1-15. [CrossRef]

121. Ceccanti, C.; Landi, M.; Incrocci, L.; Pardossi, A.; Venturi, F.; Taglieri, I.; Ferroni, G.; Guidi, L. Comparison of three domestications and wild-harvested plants for nutraceutical properties and sensory profiles in five wild edible herbs: Is domestication possible? Foods 2020, 9, 1065. [CrossRef] [PubMed]

122. Ceccanti, C.; Brizzi, A.; Landi, M.; Incrocci, L.; Pardossi, A.; Guidi, L. Evaluation of Major Minerals and Trace Elements in Wild and Domesticated Edible Herbs Traditionally Used in the Mediterranean Area. Biol. Trace Elem. Res. 2020. [CrossRef] [PubMed]

123. Cohen, S.; Koltai, H.; Selvaraj, G.; Mazuz, M.; Segoli, M.; Bustan, A.; Guy, O. Assessment of the Nutritional and Medicinal Potential of Tubers from Hairy Stork's-Bill. Plants 2020, 9, 1069. [CrossRef] [PubMed]

124. Karkanis, A.C.; Petropoulos, S.A. Physiological and growth responses of several genotypes of common purslane (Portulaca oleracea L.) under Mediterranean semi-arid conditions. Not. Bot. Horti Agrobot. Cluj-Napoca 2017, 45, 569-575. [CrossRef]

125. Karkanis, A.C.; Fernandes, A.; Vaz, J.; Petropoulos, S.; Georgiou, E.; Ciric, A.; Sokovic, M.; Oludemi, T.; Barros, L.; Ferreira, I. Chemical composition and bioactive properties of Sanguisorba minor Scop. under Mediterranean growing conditions. Food Funct. 2019, 10, 1340-1351. [CrossRef]

126. Finimundy, T.C.; Karkanis, A.; Fernandes, Â.; Petropoulos, S.A.; Calhelha, R.; Petrović, J.; Soković, M.; Rosa, E.; Barros, L.; Ferreira, I.C.F.R. Bioactive properties of Sanguisorba minor L. cultivated in central Greece under different fertilization regimes. Food Chem. 2020, 327, 127043. [CrossRef]

127. Ceccanti, C.; Landi, M.; Benvenuti, S.; Pardossi, A.; Guidi, L. Mediterranean wild edible plants: Weeds or "new functional crops"? Molecules 2018, 23, 2299. [CrossRef]

128. Petropoulos, S.; Fernandes, Â.; Karkanis, A.; Antoniadis, V.; Barros, L.; Ferreira, I. Nutrient solution composition and growing season affect yield and chemical composition of Cichorium spinosum plants. Sci. Hortic. 2018, 231, 97-107. [CrossRef]

129. Kyriacou, M.C.; Rouphael, Y.; Di Gioia, F.; Kyratzis, A.; Serio, F.; Renna, M.; De Pascale, S.; Santamaria, P. Micro-scale vegetable production and the rise of microgreens. Trends Food Sci. Technol. 2016, 57, 103-115. [CrossRef]

130. Di Gioia, F.; De Bellis, P.; Mininni, C.; Santamaria, P.; Serio, F. Physicochemical, agronomical and microbiological evaluation of alternative growing media for the production of rapini (Brassica rapa $\mathrm{L}$.) microgreens. J. Sci. Food Agric. 2017, 97, 1212-1219. [CrossRef] [PubMed]

131. Di Gioia, F.; Renna, M.; Santamaria, P. Sprouts, Microgreens and "Baby Leaf" Vegetables. In Minimally Processed Refrigerated Fruits and Vegetables; Yildiz, F., Wiley, R., Eds.; Springer: New York, NY, USA, 2017; pp. 403-432, ISBN 9781493970162.

132. Di Gioia, F.; Petropoulos, S.A.; Ozores-Hampton, M.; Morgan, K.; Rosskopf, E.N. Zinc and Iron Agronomic Biofortification of Brassicaceae Microgreens. Agronomy 2019, 9, 677. [CrossRef]

133. Pires, T.C.S.P.; Dias, M.I.; Barros, L.; Calhelha, R.C.; Alves, M.J.; Oliveira, M.B.P.P.; Santos-Buelga, C.; Ferreira, I.C.F.R.; Barreira, J.C.M.; Santos-Buelga, C.; et al. Edible flowers as sources of phenolic compounds with bioactive potential. Food Res. Int. 2018, 105, 580-588. [CrossRef] [PubMed]

134. Renna, M.; Di Gioia, F.; Leoni, B.; Mininni, C.; Santamaria, P. Culinary assessment of self-produced microgreens as basic ingredients in sweet and savory dishes. J. Culin. Sci. Technol. 2017, 15, 126-142. [CrossRef]

135. Dinu, M.; Pagliai, G.; Casini, A.; Sofi, F. Mediterranean diet and multiple health outcomes: An umbrella review of meta-analyses of observational studies and randomised trials. Eur. J. Clin. Nutr. 2018, 72, 30-43. [CrossRef]

136. Becerra-Tomás, N.; Blanco Mejía, S.; Viguiliouk, E.; Khan, T.; Kendall, C.W.C.; Kahleova, H.; Rahelić, D.; Sievenpiper, J.L.; Salas-Salvadó, J. Mediterranean diet, cardiovascular disease and mortality in diabetes: A systematic review and meta-analysis of prospective cohort studies and randomized clinical trials. Crit. Rev. Food Sci. Nutr. 2020, 60, 1207-1227. [CrossRef]

137. Feldman, E. Mediterranean diet and frailty risk. Integr. Med. Alert 2018, 21, 37-40.

138. Ciancarelli, M.; Massimo, C.; Amicis, D.; Ciancarelli, I. Mediterranean Diet and Health Promotion: Evidence and current concerns. Med. Res. Arch. 2017, 5, 1-16. [CrossRef] 
139. Di Daniele, N.D.; Noce, A.; Vidiri, M.F.; Moriconi, E.; Marrone, G.; Annicchiarico-Petruzzelli, M.; D’Urso, G.; Tesauro, M.; Rovella, V.; De Lorenzo, A.D. Impact of Mediterranean diet on metabolic syndrome, cancer and longevity. Oncotarget 2017, 8, 8947-8979. [CrossRef] [PubMed]

140. Van den Brandt, P.A. The impact of a Mediterranean diet and healthy lifestyle on premature. Am. J. Clin. Nutr. 2011, 94, 913-920. [CrossRef] [PubMed]

141. Pitsavos, C.; Panagiotakos, D.B.; Tzima, N.; Chrysohoou, C.; Economou, M. Adherence to the Mediterranean diet is associated with total antioxidant capacity in healthy adults: The ATTICA study. Am. J. Clin. Nutr. 2005, 82, 694-699. [CrossRef] [PubMed]

142. Esposito, K.; Maiorino, M.I.; Bellastella, G.; Panagiotakos, D.B.; Giugliano, D. Mediterranean diet for type 2 diabetes: Cardiometabolic benefits. Endocrine 2017, 56, 27-32. [CrossRef]

143. Buckland, G.; Travier, N.; Cottet, V.; González, C.A.; Luján-Barroso, L.; Agudo, A.; Trichopoulou, A.; Lagiou, P.; Trichopoulos, D.; Peeters, P.H.; et al. Adherence to the Mediterranean diet and risk of breast cancer in the European Prospective Investigation into Cancer and Nutrition cohort study. Int. J. Cancer 2013, 2927, 2918-2927. [CrossRef]

144. O'Connor, L.E.; Hu, E.A.; Steffen, L.M.; Selvin, E.; Rebholz, C.M. Adherence to a Mediterranean-style eating pattern and risk of diabetes in a U.S. prospective cohort study. Nutr. Diabetes 2020, 10. [CrossRef]

145. Billingsley, H.E.; Carbone, S. The antioxidant potential of the Mediterranean diet in patients at high cardiovascular risk: An in-depth review of the PREDIMED. Nutr. Diabetes 2018, 8, 1-8. [CrossRef]

146. Balabanos, D.; Savva, S.; Mitakou, S.; Mikropoulou, E.V.; Skaperda, Z.; Stagos, D.; Priftis, A.; Halabalaki, M.; Vougogiannopoulou, K.; Kouretas, D.; et al. Extracts from the Mediterranean food plants Carthamus lanatus, Cichorium intybus, and Cichorium spinosum enhanced GSH Levels and increased Nrf2 expression in human endothelial cells. Oxid. Med. Cell. Longev. 2018, 2018,1-14.

147. Pugliese, G.; Barrea, L.; Laudisio, D.; Aprano, S.; Castellucci, B.; Framondi, L.; Di Matteo, R.; Savastano, S.; Colao, A.; Muscogiuri, G. Mediterranean diet as tool to manage obesity in menopause: A narrative review. Nutrition 2020, 79-80, 110991. [CrossRef]

148. Trevisan, M.; Krogh, V.; Grioni, S.; Farinaro, E. Mediterranean diet and all-cause mortality: A cohort of Italian men. Nutr. Metab. Cardiovasc. Dis. 2020, 30, 1673-1678. [CrossRef]

149. Schwingshackl, L.; Morze, J.; Hoffmann, G. Mediterranean diet and health status: Active ingredients and pharmacological mechanisms. Br. J. Pharmacol. 2020, 177, 1241-1257. [CrossRef] [PubMed]

150. Mitka, M. Mediterranean Diet May Reduce Stroke Risk in Individuals With Genetic Predisposition to Diabetes. JAMA 2013, 310, 1013. [CrossRef] [PubMed]

151. Vitale, M.; Vaccaro, O.; Masulli, M.; Bonora, E.; Del Prato, S.; Giorda, C.B.; Nicolucci, A.; Squatrito, S.; Auciello, S.; Babini, A.C.; et al. Polyphenol intake and cardiovascular risk factors in a population with type 2 diabetes: The TOSCA.IT study. Clin. Nutr. 2017, 36, 1686-1692. [CrossRef] [PubMed]

152. Alcalay, R.N.; Gu, Y.; Mejia-santana, H.; Cote, L.; Marder, K.S.; Scarmeas, N. The Association between Mediterranean Diet Adherence and Parkinson's Disease Participants and Methods. Mov. Disord. 2012, 27, 771-774. [CrossRef] [PubMed]

153. Singh, A.; Kukreti, R.; Saso, L.; Kukreti, S. Oxidative stress: A key modulator in neurodegenerative diseases. Molecules 2019, 24, 1583. [CrossRef] [PubMed]

154. Maraki, M.I.; Yannakoulia, M.; Stamelou, M.; Stefanis, L.; Xiromerisiou, G.; Kosmidis, M.H.; Dardiotis, E.; Hadjigeorgiou, G.M.; Sakka, P.; Anastasiou, C.A.; et al. Mediterranean diet adherence is related to reduced probability of prodromal Parkinson's disease. Mov. Disord. 2019, 34, 48-57. [CrossRef]

155. Paknahad, Z.; Sheklabadi, E.; Derakhshan, Y.; Bagherniya, M.; Chitsaz, A. The effect of the Mediterranean diet on cognitive function in patients with Parkinson's disease: A randomized clinical controlled trial. Complement. Ther. Med. 2020, 50, 102366. [CrossRef]

156. Scarmeas, N.; Stern, Y.; Tang, M.; Luchsinger, J.A. Mediterranean Diet and Risk for Alzheimer's Disease. Ann. Neurol. 2006, 59, 912-921. [CrossRef]

157. Panza, F.; Lozupone, M.; Solfrizzi, V.; Custodero, C.; Valiani, V.; D’Introno, A.; Stella, E.; Stallone, R.; Piccininni, M.; Bellomo, A.; et al. Contribution of mediterranean diet in the prevention of alzheimer's disease. Role Mediterr. Diet Brain Neurodegener. Dis. 2017, 139-155. [CrossRef]

158. Scarmeas, N.; Luchsinger, J.A.; Mayeux, R.; Stern, Y. Mediterranean diet and Alzheimer disease mortality. Neurology 2007, 69, 1084-1093. [CrossRef] 
159. Masana, M.F.; Koyanagi, A.; Haro, J.M.; Tyrovolas, S. n-3 Fatty acids, Mediterranean diet and cognitive function in normal aging: A systematic review. Exp. Gerontol. 2017, 91, 39-50. [CrossRef] [PubMed]

160. Limongi, F.; Siviero, P.; Bozanic, A.; Noale, M.; Veronese, N.; Maggi, S. The Effect of Adherence to the Mediterranean Diet on Late-Life Cognitive Disorders: A Systematic Review. J. Am. Med. Dir. Assoc. 2020, 21, 1402-1409. [CrossRef] [PubMed]

161. Nowbar, A.N.; Gitto, M.; Howard, J.P.; Francis, D.P.; Al-Lamee, R. Mortality from ischemic heart disease: Analysis of data from the world health organization and coronary artery disease risk factors from NCD risk factor collaboration. Circ. Cardiovasc. Qual. Outcomes 2019, 12, 1-11. [CrossRef] [PubMed]

162. Carbone, S.; Mauro, A.G.; Mezzaroma, E.; Kraskauskas, D.; Marchetti, C.; Buzzetti, R.; Van Tassell, B.W.; Abbate, A.; Toldo, S. A high-sugar and high-fat diet impairs cardiac systolic and diastolic function in mice. Int. J. Cardiol. 2015, 198, 66-69. [CrossRef] [PubMed]

163. Martínez-González, M.A.; Gea, A.; Ruiz-Canela, M. The Mediterranean Diet and Cardiovascular Health: A Critical Review. Circ. Res. 2019, 124, 779-798. [CrossRef] [PubMed]

164. Bédard, A.; Riverin, M.; Dodin, S.; Corneau, L.; Lemieux, S. Sex differences in the impact of the Mediterranean diet on cardiovascular risk profile. Br. J. Nutr. 2012, 108, 1428-1434. [CrossRef]

165. Estruch, R.; Martínez-González, M.Á.; Corella, D.; Salas-Salvadó, J.; Ruiz-Gutiérrez, V.; Covas, M.I.; Fiol, M.; Gómez-Gracia, E.; López-Sabater, M.C.; Vinyoles, E.; et al. Effects of a Mediterranean-Style Diet on Cardiovascular Risk Factors. Ann. Intern. Med. 2006, 145, 1-11. [CrossRef]

166. Lee, J.; Pase, M.; Pipingas, A.; Raubenheimer, J.; Thurgood, M.; Villalon, L.; Macpherson, H.; Gibbs, A.; Scholey, A. Switching to a 10-day Mediterranean-style diet improves mood and cardiovascular function in a controlled crossover study. Nutrition 2015, 31, 647-652. [CrossRef]

167. Anagnostis, P.; Sfikas, G.; Gotsis, E.; Karras, S.; Athyros, V.G. Is the Beneficial Effect of Mediterranean Diet on Cardiovascular Risk Partly Mediated through Better Blood Pressure Control? Open Hypertens. J. 2013, 5 , 36-39. [CrossRef]

168. Buckland, G.; Travier, N.; Cotter, V.; González, C.A.; Luján-Barroso, L.; Agudo, A.; Trichopoulou, A.; Lagiou, P.; Trichopoulos, D.; Vilardell, M.; et al. Adherence to the mediterranean diet and risk of coronary heart disease in the spanish EPIC cohort study. Am. J. Epidemiol. 2009, 170, 1518-1529. [CrossRef]

169. Panagiotakos, D.B.; Chrysohoou, C.; Pitsavos, C.; Tzioumis, K.; Papaioannou, I.; Stefanadis, C.; Toutouzas, P. The association of Mediterranean diet with lower risk of acute coronary syndromes in hypertensive subjects. Int. J. Cardiol. 2002, 82, 141-147. [CrossRef]

170. Dontas, A.S.; Zerefos, N.S.; Panagiotakos, D.B.; Valis, D.A. Mediterranean diet and prevention of coronary heart disease in the elderly. Clin. Interv. Aging 2007, 2, 109-115. [CrossRef] [PubMed]

171. Zidan, Y.; Bouderbala, S.; Djellouli, F.; Lacaille-Dubois, M.A.; Bouchenak, M. Portulaca oleracea reduces triglyceridemia, cholesterolemia, and improves lecithin: Cholesterol acyltransferase activity in rats fed enriched-cholesterol diet. Phytomedicine 2014, 21, 1504-1508. [CrossRef] [PubMed]

172. Karimi, E.; Oskoueian, E.; Karimi, A.; Noura, R.; Ebrahimi, M. Borago officinalis L. flower: A comprehensive study on bioactive compounds and its health-promoting properties. J. Food Meas. Charact. 2018, 12, 826-838. [CrossRef]

173. Bisht, S.; Bhandari, S.; Bisht, N.S. Urtica dioica (L): An undervalued, economically important plant. Agric. Sci. Res. J. 2012, 2, 250-252.

174. Turati, F.; Carioli, G.; Bravi, F.; Ferraroni, M.; Serraino, D.; Montella, M.; Giacosa, A.; Toffolutti, F.; Negri, E.; Levi, F.; et al. Mediterranean diet and breast cancer risk. Nutrients 2018, 10, 326. [CrossRef] [PubMed]

175. Laudisio, D.; Barrea, L.; Muscogiuri, G.; Annunziata, G.; Colao, A.; Savastano, S. Breast cancer prevention in premenopausal women: Role of the Mediterranean diet and its components. Nutr. Res. Rev. 2020, 33, 19-32. [CrossRef]

176. Capurso, C.; Vendemiale, G. The Mediterranean Diet Reduces the Risk and Mortality of the Prostate Cancer: A Narrative Review. Front. Nutr. 2017, 4, 38. [CrossRef]

177. Coughlin, S.S.; Stewart, J.; Williams, L.B. A review of adherence to the Mediterranean diet and breast cancer risk according to estrogen- and progesterone-receptor status and HER2 oncogene expression. Ann. Epidemiol. Public Heal. 2018, 1, 1-13. [CrossRef]

178. Al Shaikh, A.; Braakhuis, A.J.; Bishop, K.S. The Mediterranean Diet and Breast Cancer: A Personalised Approach. Healthcare 2019, 7, 104. [CrossRef] 
179. Di Gioia, F.; Petropoulos, S.A. Phytoestrogens, phytosteroids and saponins in vegetables: Biosynthesis, functions, health effects and practical applications. In Advances in Food and Nutrition Research; Elsevier: Amsterdam, The Netherlands, 2019.

180. Bosetti, C.; Turati, F.; Pont, A.D.; Ferraroni, M.; Polesel, J.; Negri, E.; Serraino, D.; Talamini, R.; La Vecchia, C.; Zeegers, M.P. The role of Mediterranean diet on the risk of pancreatic cancer. Br. J. Cancer 2013, 109, 1360-1366. [CrossRef] [PubMed]

181. Romanos-Nanclares, A.; Sánchez-Quesada, C.; Gardeazábal, I.; Martínez-González, M.Á.; Gea, A.; Toledo, E. Phenolic Acid Subclasses, Individual Compounds, and Breast Cancer Risk in a Mediterranean Cohort: The SUN Project. J. Acad. Nutr. Diet. 2020, 120, 1002-1015.e5. [CrossRef] [PubMed]

182. Jaramillo, S.; Muriana, F.J.G.; Guillen, R.; Jimenez-Araujo, A.; Rodriguez-Arcos, R.; Lopez, S. Saponins from edible spears of wild asparagus inhibit AKT, p70S6K, and ERK signalling, and induce apoptosis through G0/G1 cell cycle arrest in human colon cancer HCT-116 cells. J. Funct. Foods 2016, 26, 1-10. [CrossRef]

183. Mikropoulou, E.V.; Vougogiannopoulou, K.; Kalpoutzakis, E.; Sklirou, A.D.; Skaperda, Z.; lle Houriet, J.; Wolfender, J.L.; Trougakos, I.P.; Kouretas, D.; Halabalaki, M.; et al. Phytochemical composition of the decoctions of Greek edible greens (chórta) and evaluation of antioxidant and cytotoxic properties. Molecules 2018, 23, 1541. [CrossRef]

184. Bilušić, T.; Šola, I.; Rusak, G.; Poljuha, D.; Čikeš Čulić, V. Antiproliferative and pro-apoptotic activities of wild asparagus (Asparagus acutifolius L.), black bryony (Tamus communis L.) and butcher's broom (Ruscus aculeatus L.) aqueous extracts against T24 and A549 cancer cell lines. J. Food Biochem. 2019, 43, 1-9. [CrossRef]

185. Ryu, D.S.; Kim, S.H.; Lee, D.S. Anti-proliferative effect of polysaccharides from Salicornia herbacea on induction of G2/M arrest and apoptosis in human colon cancer cells. J. Microbiol. Biotechnol. 2009, 19, 1482-1489. [CrossRef]

186. Di Gioia, F.; Pinela, J.; de Haro Bailón, A.; Fereira, I.C.; Petropoulos, S.A. The dilemma of "good" and "bad" glucosinolates and the potential to regulate their content. In Glucosinolates: Properties, Recovery, and Applications; Galanakis, C.M., Ed.; Academic Press: London, UK, 2019; Volume 1, pp. 1-45, ISBN 9780128164938.

187. Mandrich, L.; Caputo, E. Brassicaceae-derived anticancer agents: Towards a green approach to beat cancer. Nutrients 2020, 12, 868. [CrossRef]

188. Petropoulos, S.A.; Di Gioia, F.; Ntatsi, G. Vegetable organosulfur compounds and their health promoting effects. Curr. Pharm. Des. 2017, 23, 1-26. [CrossRef]

189. Wade, A.T.; Elias, M.F.; Murphy, K.J. Adherence to a Mediterranean diet is associated with cognitive function in an older non-Mediterranean sample: Findings from the Maine-Syracuse Longitudinal Study. Nutr. Neurosci. 2019, 1-12. [CrossRef]

190. Bourre, J.M. Diet, Brain Lipids, and Brain Functions: Polyunsaturated Fatty Acids, Mainly Omega-3 Fatty Acids. In Handbook of Neurochemistry and Molecular Neurobiology; Tettamanti, G., Goracci, G., Eds.; Springer: New York, NY, USA, 2009; pp. 410-441.

191. Bourre, J.M. Dietary omega-3 Fatty acids and psychiatry: Mood, behaviour, stress, depression, dementia and aging. J. Nutr. Heal. Aging 2005, 9, 31-38.

192. Bourre, J.M. Roles of unsaturated fatty acids (especially omega-3 fatty acids) in the brain at various ages and during ageing. J. Nutr. Heal. Aging 2004, 8, 163-174.

193. Mcmillan, L.; Owen, L.; Kras, M.; Scholey, A. Behavioural effects of a 10-day Mediterranean diet. Results from a pilot study evaluating mood and cognitive performance. Appetite 2011, 56, 143-147. [CrossRef] [PubMed]

194. Ferrer-Cascales, R.; Albaladejo-Blázquez, N.; Ruiz-Robledillo, N.; Rubio-Aparicio, M.; Laguna-Pérez, A.; Zaragoza-Martí, A. Low adherence to the mediterranean diet in isolated adolescents: The mediation effects of stress. Nutrients 2018, 10, 1894. [CrossRef] [PubMed]

195. Cano, A.; Marshall, S.; Zolfaroli, I.; Bitzer, J.; Ceausu, I.; Chedraui, P.; Durmusoglu, F.; Erkkola, R.; Goulis, D.G.; Hirschberg, A.L.; et al. The Mediterranean diet and menopausal health: An EMAS position statement. Maturitas 2020, 139, 90-97. [CrossRef] [PubMed]

196. Echeverría, G.; McGee, E.E.; Urquiaga, I.; Jiménez, P.; D’Acuña, S.; Villarroel, L.; Velasco, N.; Leighton, F.; Rigotti, A. Inverse associations between a locally validated Mediterranean diet index, overweight/obesity, and metabolic syndrome in Chilean adults. Nutrients 2017, 9, 862. [CrossRef] 
197. Esposito, K.; Maiorino, M.I.; Bellastella, G.; Chiodini, P.; Panagiotakos, D.; Giugliano, D. A journey into a Mediterranean diet and type 2 diabetes: A systematic review with meta-analyses. BMJ Open 2015, 5. [CrossRef]

198. Núñez-Córdoba, J.M.; Valencia-Serrano, F.; Toledo, E.; Alonso, A.; Martínez-González, M.A. The Mediterranean diet and incidence of hypertension: The Seguimiento Universidad de Navarra (SUN) study. Am. J. Epidemiol. 2009, 169, 339-346. [CrossRef]

199. Bendinelli, B.; Masala, G.; Bruno, R.M.; Caini, S.; Saieva, C.; Boninsegni, A.; Ungar, A.; Ghiadoni, L.; Palli, D. A priori dietary patterns and blood pressure in the EPIC Florence cohort: A cross-sectional study. Eur. J. Nutr. 2019, 58, 455-466. [CrossRef]

200. Nissensohn, M.; Román-Viñas, B.; Sánchez-Villegas, A.; Piscopo, S.; Serra-Majem, L. The Effect of the Mediterranean Diet on Hypertension: A Systematic Review and Meta-Analysis. J. Nutr. Educ. Behav. 2016, 48, 42-53.e1. [CrossRef]

201. Hernáez, Á.; Castañer, O.; Elosua, R.; Pintó, X.; Estruch, R.; Salas-Salvadó, J.; Corella, D.; Arós, F.; Serra-Majem, L.; Fiol, M.; et al. Mediterranean Diet Improves High-Density Lipoprotein Function in High-Cardiovascular-Risk Individuals. Circulation 2017, 135, 633-643. [CrossRef]

202. Murie-Fernandez, M.; Irimia, P.; Toledo, E.; Martínez-Vila, E.; Buil-Cosiales, P.; Serrano-Martínez, M.; Ruiz-Gutiérrez, V.; Ros, E.; Estruch, R.; Martínez-González, M. ángel Carotid intima-media thickness changes with Mediterranean diet: A randomized trial (PREDIMED-Navarra). Atherosclerosis 2011, 219, 158-162. [CrossRef] [PubMed]

203. Romaguera, D.; Norat, T.; Vergnaud, A.C.; Mouw, T.; May, A.M.; Agudo, A.; Buckland, G.; Slimani, N.; Rinaldi, S.; Couto, E.; et al. Mediterranean dietary patterns and prospective weight change in participants of the EPIC-PANACEA project. Am. J. Clin. Nutr. 2010, 92, 912-921. [CrossRef] [PubMed]

204. Romaguera, D. Mediterranean diet and type 2 diabetes risk in the European prospective investigation into cancer and nutrition (EPIC) study: The interAct project. Diabetes Care 2011, 34, 1913-1918. [PubMed]

205. Schwingshackl, L.; Schwedhelm, C.; Galbete, C.; Hoffmann, G. Adherence to mediterranean diet and risk of cancer: An updated systematic review and meta-analysis. Nutrients 2017, 9, 1063. [CrossRef]

206. Kenfield, S.A.; Dupre, N.; Richman, E.L.; Stampfer, M.J.; Chan, J.M.; Giovannucci, E.L. Mediterranean diet and prostate cancer risk and mortality in the health professionals follow-up study. Eur. Urol. 2014, 65, 887-894. [CrossRef]

207. Trichopoulou, A.; Costacou, T.; Bamia, C.; Trichopoulos, D. Adherence to a Mediterranean Diet and Survival in a Greek Population. N. Engl. J. Med. 2003, 348, 2599-2608. [CrossRef]

208. Bhushan, A.; Fondell, E.; Ascherio, A.; Yuan, C.; Grodstein, F.; Willett, W. Adherence to Mediterranean diet and subjective cognitive function in men. Eur. J. Epidemiol. 2018, 33, 223-234. [CrossRef]

209. Fung, T.; Rexrode, K.; Mantzoros, C.; Manson, J.; Willet, W.; Hu, F. Mediterranean diet and incidence and mortality of coronary heart disease and stroke in women. Circulation 2009, 119, 1093-1100. [CrossRef]

210. Jennings, A.; Cashman, K.D.; Gillings, R.; Cassidy, A.; Tang, J.; Fraser, W.; Dowling, K.G.; Hull, G.L.J.; Berendsen, A.A.M.; De Groot, L.C.P.G.M.; et al. A Mediterranean-like dietary pattern with Vitamin D3 $(10 \mu \mathrm{g} / \mathrm{d})$ supplements reduced the rate of bone loss in older Europeans with osteoporosis at baseline: Results of a 1-y randomized controlled trial. Am. J. Clin. Nutr. 2018, 108, 633-640. [CrossRef]

211. Lassale, C.; Batty, G.D.; Baghdadli, A.; Jacka, F.; Sánchez-Villegas, A.; Kivimäki, M.; Akbaraly, T. Healthy dietary indices and risk of depressive outcomes: A systematic review and meta-analysis of observational studies. Mol. Psychiatry 2019, 24, 965-986. [CrossRef]

212. Carlos, S.; De La Fuente-Arrillaga, C.; Bes-Rastrollo, M.; Razquin, C.; Rico-Campà, A.; Martínez-González, M.A.; Ruiz-Canela, M. Mediterranean diet and health outcomes in the SUN cohort. Nutrients 2018, 10, 439. [CrossRef] [PubMed]

213. Anastasiou, C.A.; Yannakoulia, M.; Kosmidis, M.H.; Dardiotis, E.; Hadjigeorgiou, G.M.; Sakka, P.; Arampatzi, X.; Bougea, A.; Labropoulos, I.; Scarmeas, N. Mediterranean diet and cognitive health: Initial results from the Hellenic Longitudinal Investigation of Ageing and Diet. PLoS ONE 2017, 12, 1-18. [CrossRef] [PubMed]

214. Savanelli, M.C.; Barrea, L.; Macchia, P.E.; Savastano, S.; Falco, A.; Renzullo, A.; Scarano, E.; Nettore, I.C.; Colao, A.; Somma, C. Preliminary results demonstrating the impact of Mediterranean diet on bone health. J. Transl. Med. 2017, 15, 1-8. [CrossRef] [PubMed] 
215. Estruch, R.; Ros, E.; Salas-Salvadó, J.; Covas, M.-I.; Corella, D.; Arós, F.; Gómez-Gracia, E.; Ruiz-Gutiérrez, V.; Fiol, M.; Lapetra, J.; et al. Primary Prevention of Cardiovascular Disease with a Mediterranean Diet Supplemented with Extra-Virgin Olive Oil or Nuts. N. Engl. J. Med. 2018, 378, e34. [CrossRef]

216. Sofi, F.; Abbate, R.; Gensini, G.F.; Casini, A. Accruing evidence on benefits of adherence to the Mediterranean diet on health: An updated systematic review and meta-analysis. Am. J. Clin. Nutr. 2010, 92, 1189-1196. [CrossRef] [PubMed]

217. Rodriguez, A.; Curhan, G.C.; Gambaro, G.; Taylor, E.N.; Ferraro, P.M. Mediterranean diet adherence and risk of incident kidney stones. Am. J. Clin. Nutr. 2020. [CrossRef] [PubMed]

218. Kössler, T.; Weber, K.S.; Wölwer, W.; Hoyer, A.; Strassburger, K.; Burkart, V.; Szendroedi, J.; Roden, M.; Müssig, K.; Roden, M.; et al. Associations between cognitive performance and Mediterranean dietary pattern in patients with type 1 or type 2 diabetes mellitus. Nutr. Diabetes 2020, 10, 4-9. [CrossRef]

219. Corley, J.; Cox, S.R.; Taylor, A.M.; Hernandez, M.V.; Maniega, S.M.; Ballerini, L.; Wiseman, S.; Meijboom, R.; Backhouse, E.V.; Bastin, M.E.; et al. Dietary patterns, cognitive function, and structural neuroimaging measures of brain aging. Exp. Gerontol. 2020, 142, 111117. [CrossRef]

220. Kelly, M.E.; Duff, H.; Kelly, S.; McHugh Power, J.E.; Brennan, S.; Lawlor, B.A.; Loughrey, D.G. The impact ofsocial activities, social networks, social support and social relationships on the cognitive functioning of healthy older adults: A systematic review. Syst. Rev. 2017, 6. [CrossRef]

221. Wu, L.; Sun, D. Adherence to Mediterranean diet and risk of developing cognitive disorders: An updated systematic review and meta-analysis of prospective cohort studies. Sci. Rep. 2017, 7, 1-9. [CrossRef]

222. Godos, J.; Ferri, R.; Caraci, F.; Cosentino, F.I.I.; Castellano, S.; Galvano, F.; Grosso, G. Adherence to the mediterranean diet is associated with better sleep quality in Italian adults. Nutrients 2019, 11, 976. [CrossRef] [PubMed]

223. Gianfredi, V.; Nucci, D.; Tonzani, A.; Amodeo, R.; Benvenuti, A.L.; Villarini, M.; Moretti, M. Sleep disorder, Mediterranean Diet and learning performance among nursing students: inSOMNIA, a cross-sectional study. Ann. Ig. 2018, 30, 470-481. [PubMed]

224. Campanini, M.Z.; Guallar-Castillón, P.; Rodríguez-Artalejo, F.; Lopez-Garcia, E. Mediterranean diet and changes in sleep duration and indicators of sleep quality in older adults. Sleep 2017, 40,1-9. [CrossRef]

225. Cavaliere, A.; De Marchi, E.; Banterle, A. Exploring the adherence to the mediterranean diet and its relationship with individual lifestyle: The role of healthy behaviors, pro-environmental behaviors, income, and education. Nutrients 2018, 10, 141. [CrossRef]

226. Kim, M.J.; Hall, C.M.; Kim, D.K. Predicting environmentally friendly eating out behavior by value-attitude-behavior theory: Does being vegetarian reduce food waste? J. Sustain. Tour. 2020, 28, 797-815. [CrossRef]

227. Kearney, J. Food consumption trends and drivers. Philos. Trans. R. Soc. B Biol. Sci. 2010, 365, $2793-2807$. [CrossRef] [PubMed]

228. Coats, L.; Aboul-Enein, B.H.; Dodge, E.; Benajiba, N.; Kruk, J.; Khaled, M.B.; Diaf, M.; El Herrag, S.E. Perspectives of Environmental Health Promotion and the Mediterranean Diet: A Thematic Narrative Synthesis. J. Hunger Environ. Nutr. 2020, 1-23. [CrossRef]

229. Dernini, S.; Berry, E.M. Mediterranean Diet: From a Healthy Diet to a Sustainable Dietary Pattern. Front. Nutr. 2015, 2, 1-7. [CrossRef]

230. Carlos, M.; Elena, B.; Teresa, I.M. Are Adherence to the Mediterranean Diet, Emotional Eating, Alcohol Intake, and Anxiety Related in University Students in Spain? Nutrients 2020, 12, 2224. [CrossRef]

231. Lanfranchi, M.; Calabrò, G.; De Pascale, A.; Fazio, A.; Giannetto, C. Household food waste and eating behavior: Empirical survey. Br. Food J. 2016, 118, 3059-3072. [CrossRef]

232. Sarti, S.; Terraneo, M.; Tognetti Bordogna, M. Poverty and private health expenditures in Italian households during the recent crisis. Health Policy 2017, 121, 307-314. [CrossRef] [PubMed]

233. Manios, Y.; Costarelli, V. Childhood Obesity in the WHO European Region. In Epidemiology of Obesity in Children and Adolescents; Moreno, L.A., Pigeot, I., Ahrens, W., Eds.; Springer International Publishing: New York, NY, USA, 2011; pp. 43-68, ISBN 9781441960399.

234. Blas, A.; Garrido, A.; Unver, O.; Willaarts, B. A comparison of the Mediterranean diet and current food consumption patterns in Spain from a nutritional and water perspective. Sci. Total Environ. 2019, 664, 1020-1029. [CrossRef] [PubMed] 
235. Sánchez, P.H.; Ruano, C.; de Irala, J.; Ruiz-Canela, M.; Martínez-González, M.; Sánchez-Villegas, A. Adherence to the Mediterranean diet and quality of life in the SUN Project. Eur. J. Clin. Nutr. 2012, 66, 360-368. [CrossRef] [PubMed]

236. Veronese, N.; Notarnicola, M.; Cisternino, A.M.; Inguaggiato, R.; Guerra, V.; Reddavide, R.; Donghia, R.; Rotolo, O.; Zinzi, I.; Leandro, G.; et al. Trends in adherence to the Mediterranean diet in South Italy: A cross sectional study. Nutr. Metab. Cardiovasc. Dis. 2020, 30, 410-417. [CrossRef]

237. Renna, M.; Gonnella, M. Ethnobotany, Nutritional Traits, and Healthy Properties of Some Halophytes Used as Greens in the Mediterranean Basin. Handb. Halophytes 2020, 1-19. [CrossRef]

238. Renna, M.; Montesano, F.; Signore, A.; Gonnella, M.; Santamaria, P. BiodiverSO: A Case Study of Integrated Project to Preserve the Biodiversity of Vegetable Crops in Puglia (Southern Italy). Agriculture 2018, 8, 128. [CrossRef]

239. Korre, M.; Tsoukas, M.A.; Frantzeskou, E.; Yang, J.; Kales, S.N. Mediterranean Diet and Workplace Health Promotion. Curr. Cardiovasc. Risk Rep. 2014, 8, 1-7. [CrossRef]

240. Avital, K.; Buch, A.; Hollander, I.; Brickner, T.; Goldbourt, U. Adherence to a Mediterranean diet by vegetarians and vegans as compared to omnivores. Int. J. Food Sci. Nutr. 2020, 71, 378-387. [CrossRef]

241. Chrysargyris, A.; Kloukina, C.; Vassiliou, R.; Tomou, E.M.; Skaltsa, H.; Tzortzakis, N. Cultivation strategy to improve chemical profile and anti-oxidant activity of Sideritis perfoliata L. subsp. perfoliata. Ind. Crops Prod. 2019, 140, 111694. [CrossRef]

242. Konuk, F.A. The influence of perceived food quality, price fairness, perceived value and satisfaction on customers' revisit and word-of-mouth intentions towards organic food restaurants. J. Retail. Consum. Serv. 2019, 50, 103-110. [CrossRef]

243. Lai, P.H.; Chuang, S.T.; Zhang, M.C.; Nepal, S.K. The non-profit sharing economy from a social exchange theory perspective: A case from World Wide Opportunities on Organic Farms in Taiwan. J. Sustain. Tour. 2020, 28, 1970-1987. [CrossRef]

244. Asian, S.; Hafezalkotob, A.; John, J.J. Sharing economy in organic food supply chains: A pathway to sustainable development. Int. J. Prod. Econ. 2019, 218, 322-338. [CrossRef]

Publisher's Note: MDPI stays neutral with regard to jurisdictional claims in published maps and institutional affiliations.

(C) 2020 by the authors. Licensee MDPI, Basel, Switzerland. This article is an open access article distributed under the terms and conditions of the Creative Commons Attribution (CC BY) license (http://creativecommons.org/licenses/by/4.0/). 